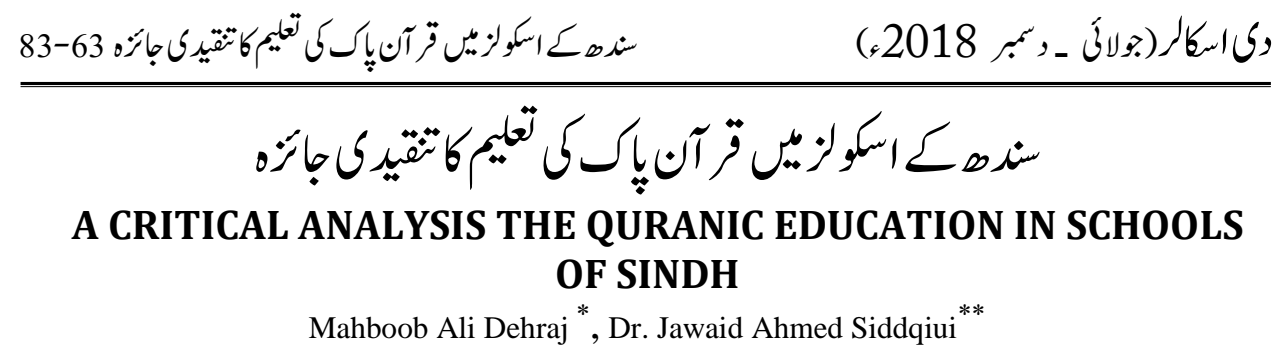

The Scholar Islamic Academic Research Journal || Web: www.siarj.com || P. ISSN: 2413-7480 || Vol. 4, No. 2 || July -December 2018 || P. 63-83

DOI: $10.29370 /$ siarj/issue7ar4

URL: https://doi.org/10.29370/siarj/issue7ar4

License: Copyright c 2017 NC-SA 4.0

\begin{abstract}
:
Pakistan is an Islamic country; it came in to being in the world on the name of Islam. Its foundation was on the basis of Quran teaching .Quran is the complete code of life and helps our students to face the challenges of hour. in this paper researcher go through the matter and sought out the study the current Quran education in the schools of Sindh .for this study three objectives were made to find the problem 1).To analysis the current education of Quran in schools of Sindh. 2) To study the role of teacher in teaching of holy Quran.3) to assess the interest of learners in learning of holy Quran. The Survey method was used and population of this study was schools of Sindh and due to large population stratified sampling was selected the data was analyzed by using simple statics like percentage, Finding showed that the 90\%views were against the attitude of administration regarding the quaint education at secondary schools, same attitudes of teachers, parents to toward this education similarly the protocol interviews were conducted from the senior educationist, they were agreed that the major stock holder, admin teachers, parents have no interest in this subject. While in assessment of Quran was not proper, the student have not given any reward in the learning of this book though the Arabic teachers and $H, M$
\end{abstract}

${ }^{*}$ Ph.D. Scholar at Hamdard University Karachi, Assistant Professor, School of Education, Shaheed Benazir Bhutto University, Nawabshad, Pakistan. Email: mehboobali@sbbusba.edu.pk

ORCID ID: https://orcid.org/0000-0002-2840-7836

${ }^{* *}$ Dean Faculty of Social Sciences, Sindh institute of management and technology Karachi.Email: Dean.soc.sci@ simat.edu.pk 
they just perform formality and not sincere in teaching of this subject, it is recommended that teacher admin and parent must come forward and ensure the proper assessment of this important book and Government also separately section teaching post for this subject.

Keywords: Quranic, Education, Teaching, Schools, Sindh,

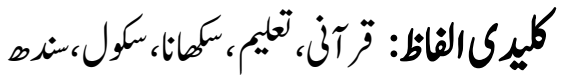

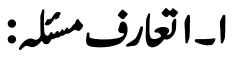

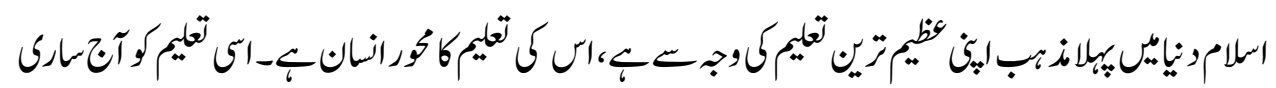

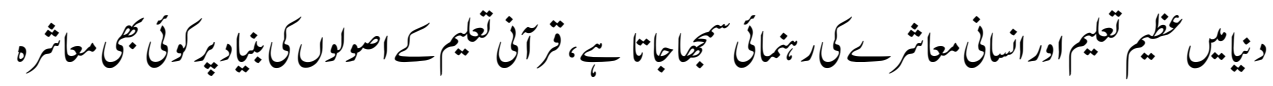

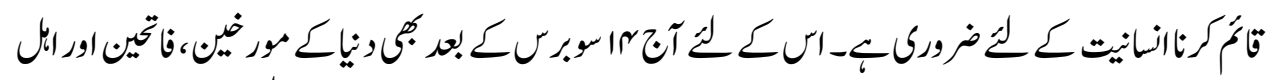

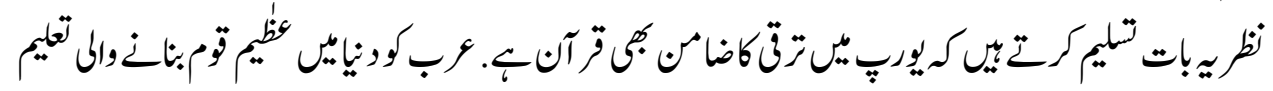

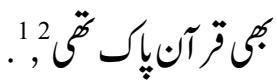

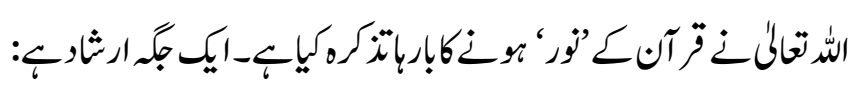

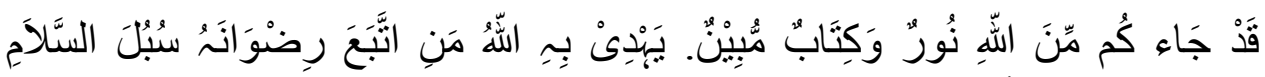

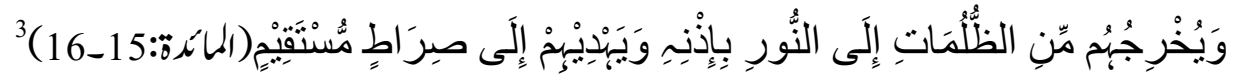

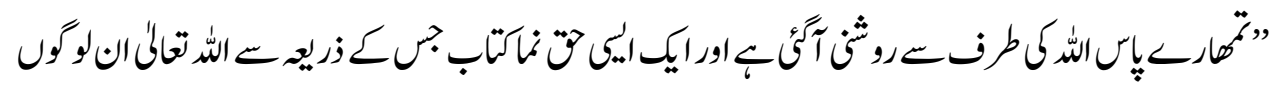

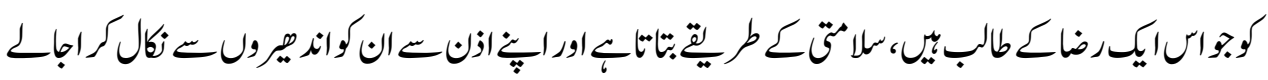

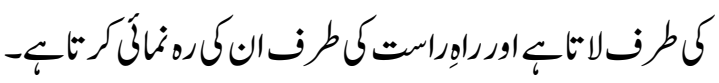

\footnotetext{
${ }^{1}$ Najeeb Allah Abadi, History of islam, Nafis Academy Karachi, 1959 p. 55.1

2 Yilmaz, I. Muslim laws, politics and society in modern nation states: Dynamic legal pluralisms in England, Turkey and Pakistan. Routledge.(2016) 


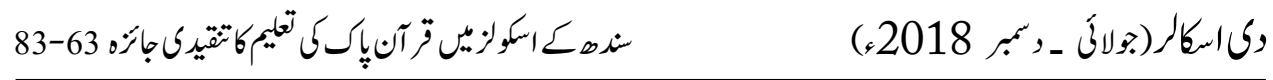

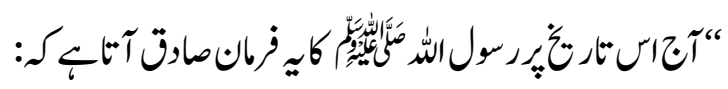

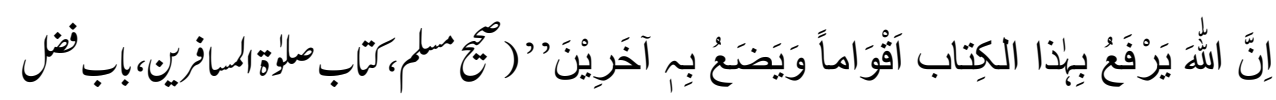

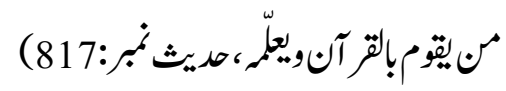

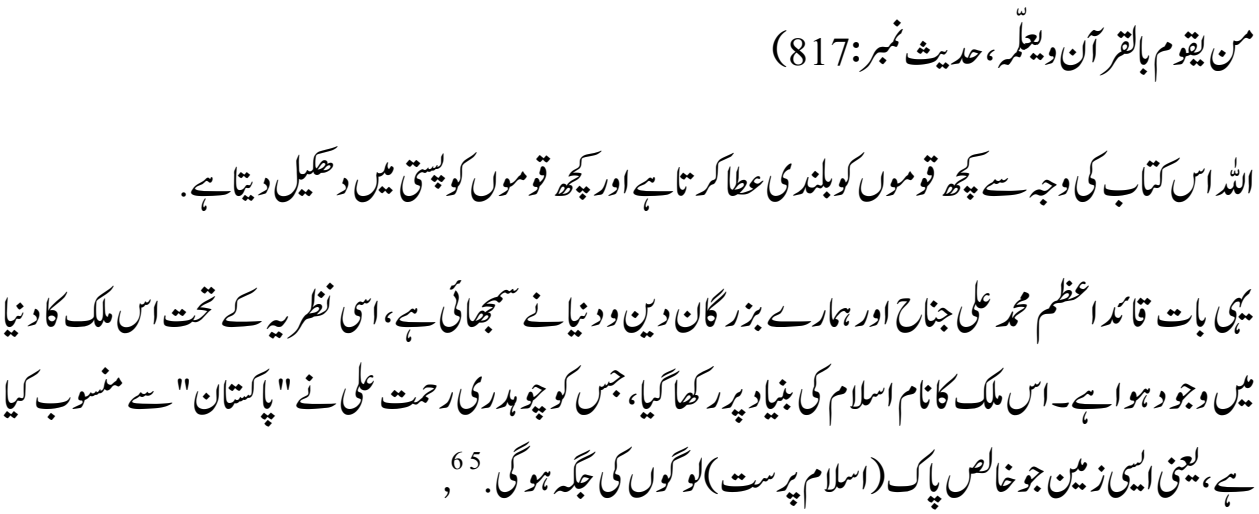

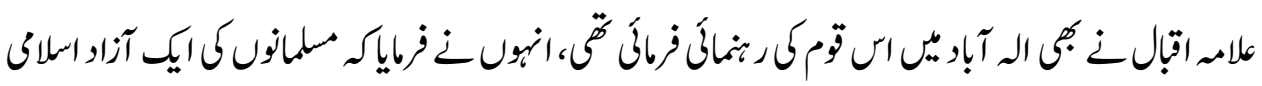

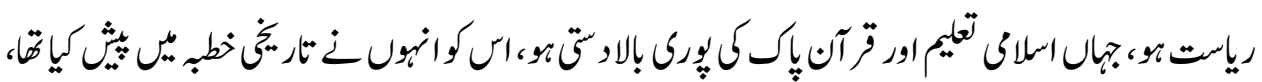

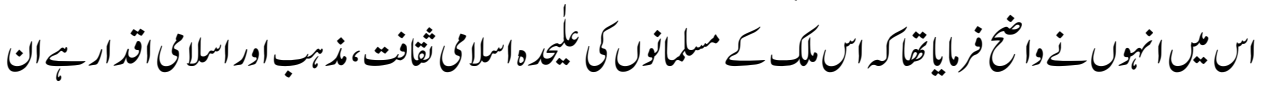

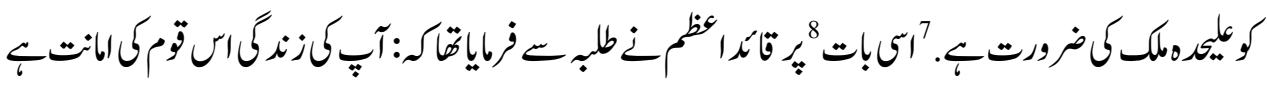

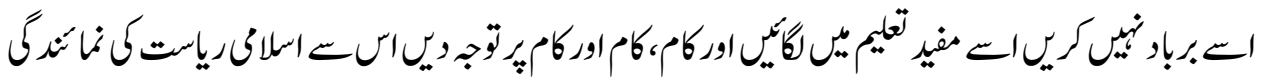

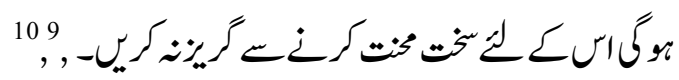

${ }^{4}$ Sheikh, Muhammad, and Muhammad Bhatti, "Impact of Islamic Management Principles on Organizations Regardless of Religion." Int. J. of Multidisciplinary and Current research 5 (2017).

${ }_{5}^{5}$ Raises Naveed Ahmed Qayyad and his Alliance, The Popular Academy of 1966, p. 344.33

${ }^{6}$ Al Sager, A. W. Re-presenting Muslims and Islam: A critical discourse analysis Orientalism in high school world history textbooks (Doctoral dissertation, Tennessee Technological University).(216)

${ }^{7}$ Raises Naveed Ahmed

${ }^{8}$ Zelizer, V. A. R. Morals and markets: The development of life insurance in the United States. Columbia University Press. (2017).

9 Raises Naveed Ahmed, Qayyad and his Alliance, The Popular Academy of 1966, p. 344.33

${ }^{10}$ Merchant, N. H,Unflattening the Muslim-Other in Social Studies: Student Perspectives \& Curricular Approaches (Doctoral dissertation) . 2015. 


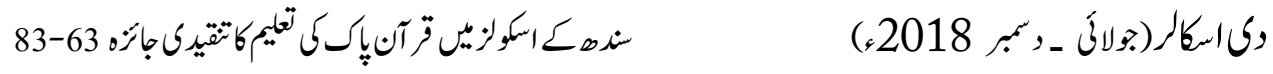

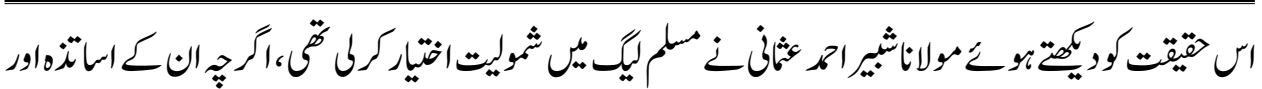

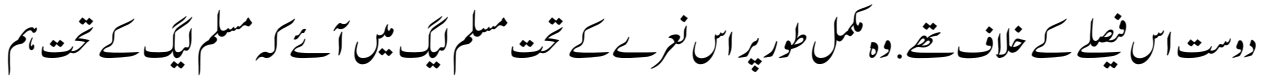

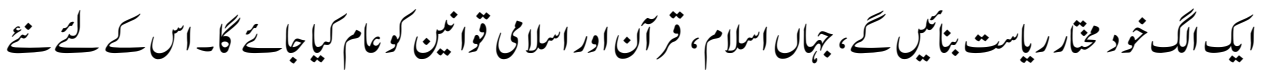

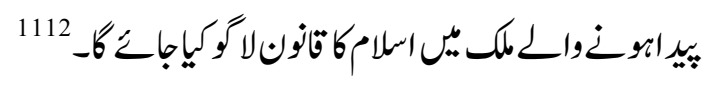

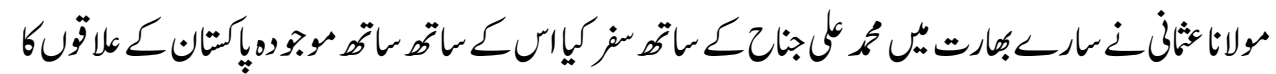

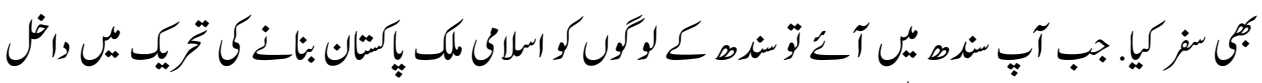

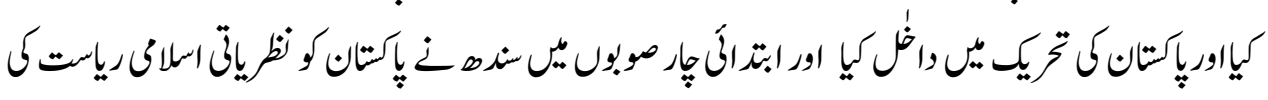
بنياريرووط وإقة.

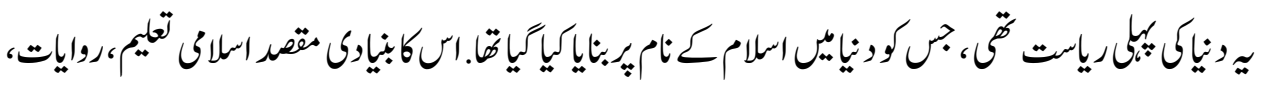

$$
\begin{aligned}
& \text { اسلاق اقترار اوررواياتتك هفاظت كرناقة. } 1514
\end{aligned}
$$

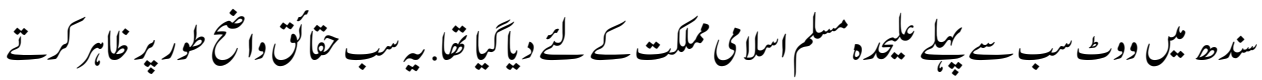

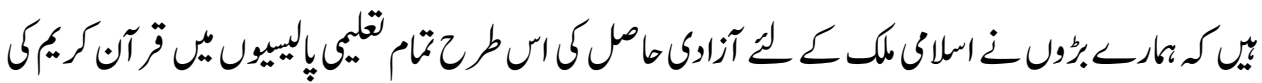

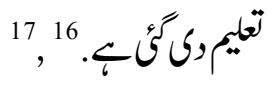

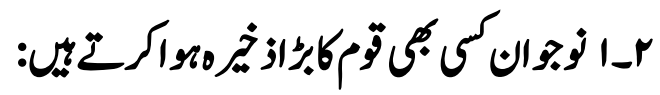

\footnotetext{
${ }^{11}$ Raises Naveed Ahmed, Qayyad and his Alliance, The Popular Academy of 1966, p.344.33

${ }^{12}$ Rais, RasulBakhsh. Imagining Pakistan: Modernism, State, and the Politics of Islamic Revival. Lexington Books, 2017

${ }^{13}$ Raises Naveed Ahmed, Qayyad and his Alliance, The Popular Academy of 1966, p. 344.33

${ }^{14}$ Saleem Manoor,madaris min taleem islmaic, Pakistan studes islamic islam abad I,I,u,islam abad 2002

15 Ali, ShaheenSardar. "Law, Islam and the women's movement in Pakistan." In International Perspectives on Gender and Democratization, pp. 41-63. Palgrave Macmillan UK, 2000.

${ }^{16}$ Qureshi Ishtyaq

${ }^{17}$ Merchant, N. H,Unflattening the Muslim-Other in Social Studies: Student Perspectives \& Curricular Approaches (Doctoral dissertation) . 2015.
} 


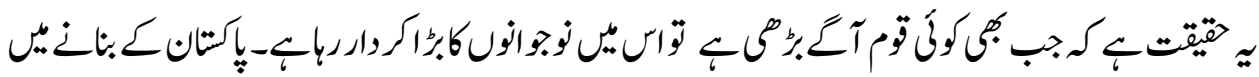

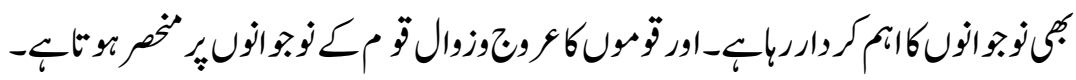

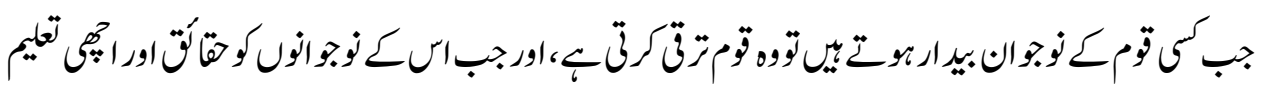

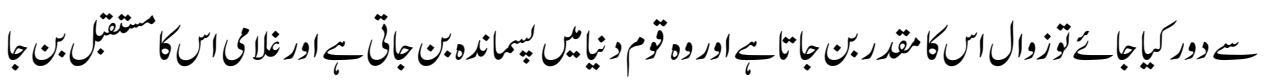

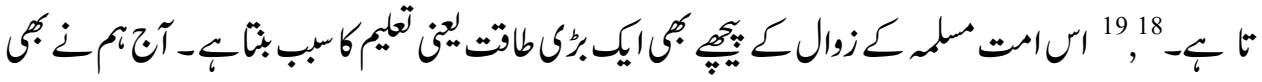

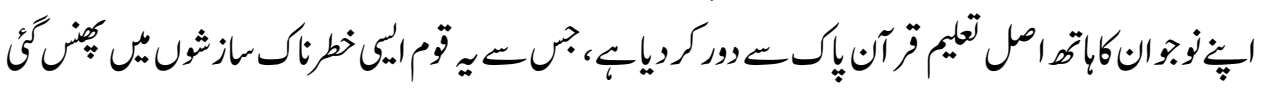

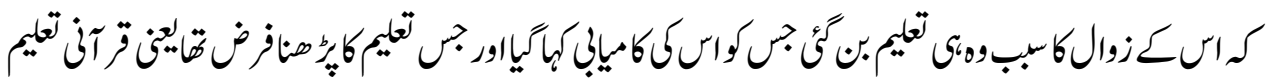

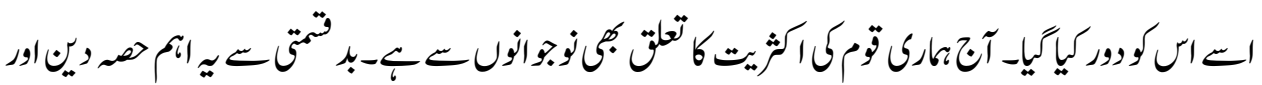

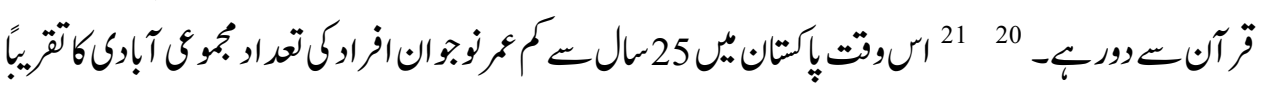

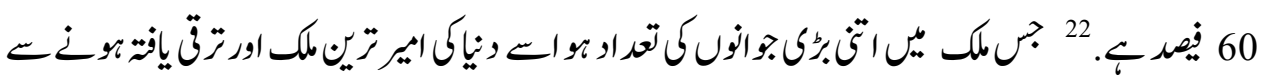

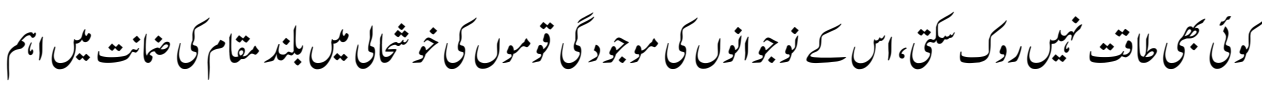

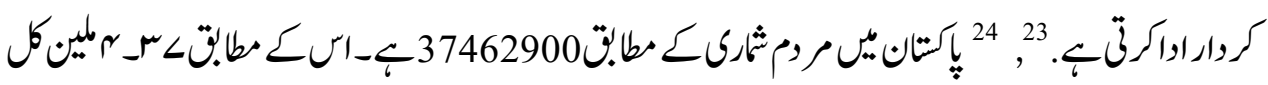

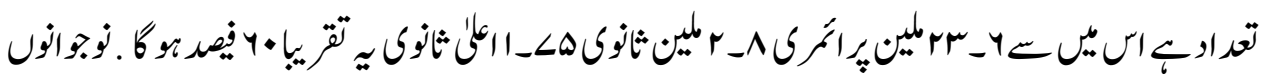

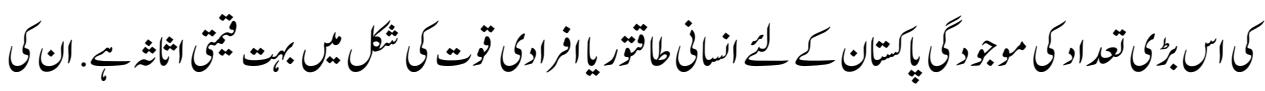

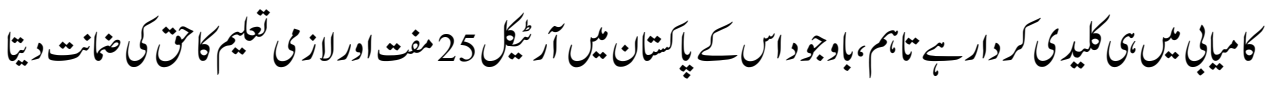

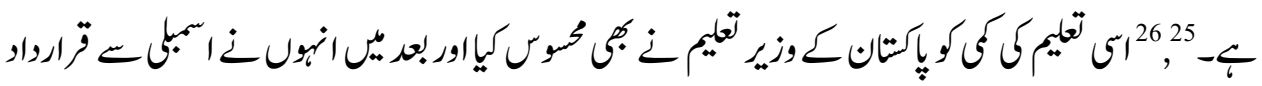

\footnotetext{
${ }^{18}$ Rais, RasulBakhsh. Imagining Pakistan: Modernism, State, and the Politics of Islamic Revival. Lexington Books, 2017.

${ }^{19}$ Mansoor Saleem Madaris men taleem Islami, Pakistan studes islamic islam abad I,I,u,islam abad 2002

${ }^{20}$ Cochrane, Iain. The Causes of the Bangladesh War. Lulu. Com, 2009.

${ }^{21}$ Ghazi Dr Mahmood Ahmed, Madaris min taleem Islami, Pakistan studies Islamic islam abad I,I,u,islam abad 2002

${ }^{22}$ Ahmed Javeed Choderi, www.dailyurdunews.com/javedchaudhry/

${ }^{23}$ Arnett, Jeffrey Jensen. Adolescence and emerging adulthood. Boston, MA: Pearson, 2014.

${ }^{24}$ Ahmed Javeed Choderi, www.dailyurdunews.com/javedchaudhry/

${ }^{25}$ www.sindheducation.gov.pk/Contents/Menu/Final\%20SESP.pdf
} 


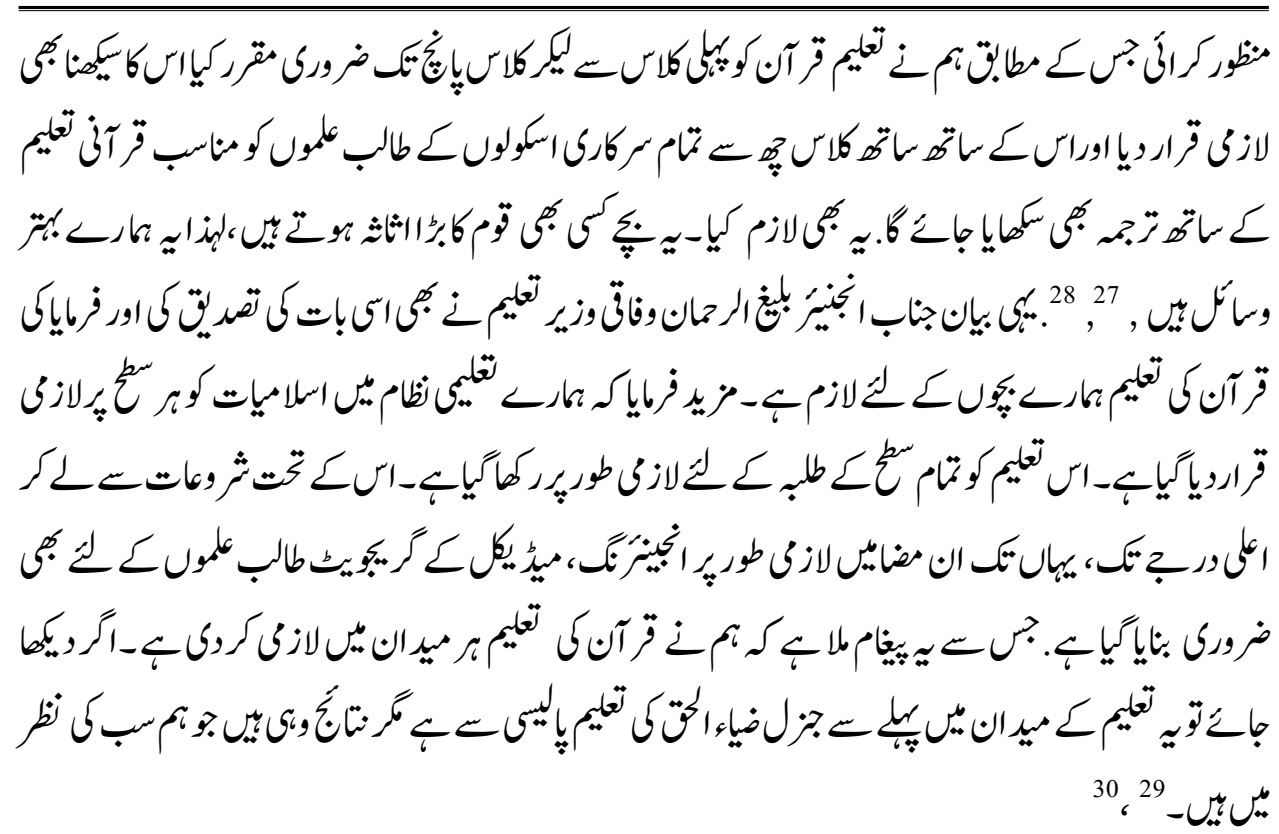

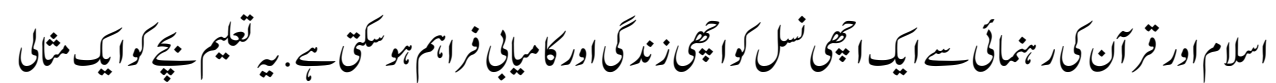

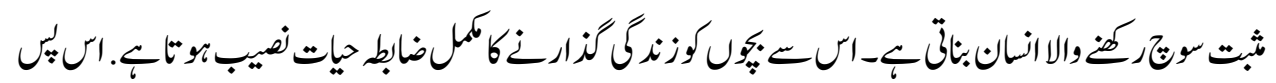

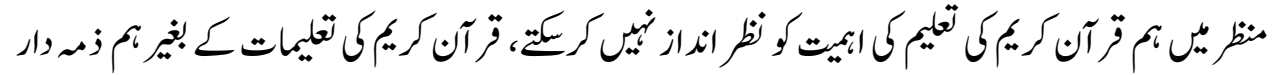

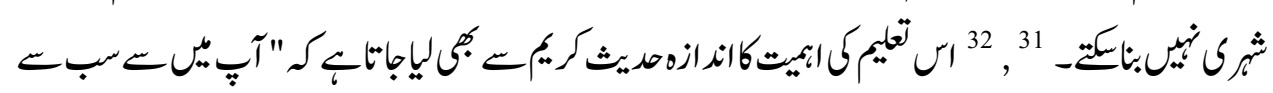

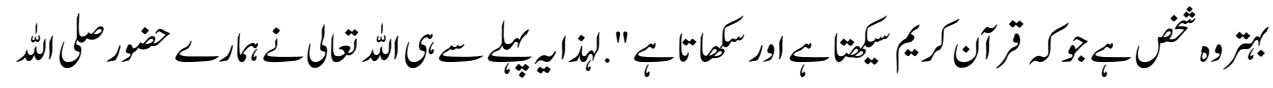

\footnotetext{
${ }^{26}$ Bhayo, Nadir Hussain, Qin Yuyou, Wenjing Zeng, and Jingjing Dong. "Role of District Education Officials in Quality Education in Nanguan and Shikarpur Districts: A Comparative Study Between China and Pakistan." language 9, no. 26 (2018).

${ }^{27}$ Ahmed, N., \& Aziz, S. A. (2018). Critical analysis of the role of foreign AID agencies in the improvement of education and living style of the rural society of Sindh.

${ }^{28}$ Qaiser Banghali history of education Sindh government education department Sindh 1998

${ }^{29}$ Rugh, William A. "Education in Saudi Arabia: choices and constraints." Middle East Policy 9, no. 2, 2002.:P. 40.

${ }^{30}$ Wfaqi Telim Pakistan Web Site

${ }^{31}$ Chowdhury, F.D.Theorising patriarchy: the Bangladesh context. Asian Journal of Soc(2009).ial Science, 37(4),599-622.

32 Jalindery Muhammad Hanief, waffa qul madaris multan Pakistan, vol. 3-2006
} 


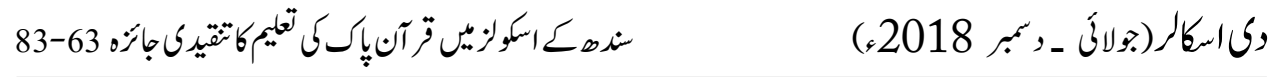

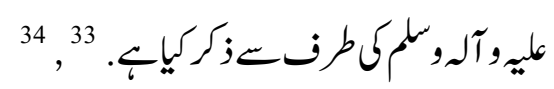

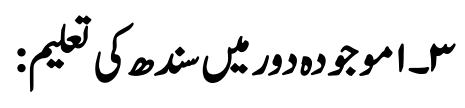

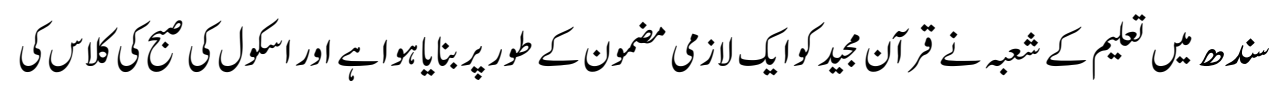

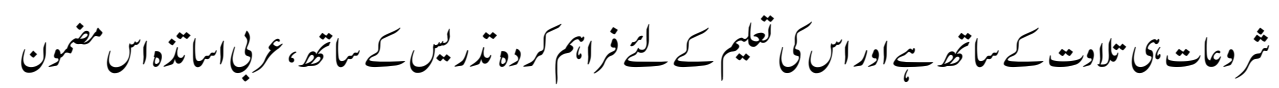

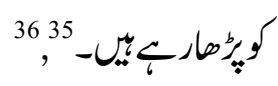

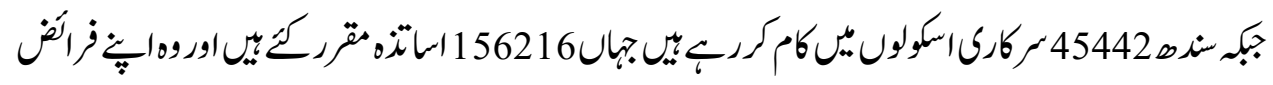

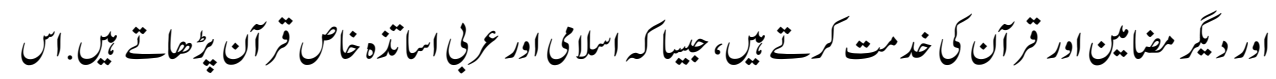

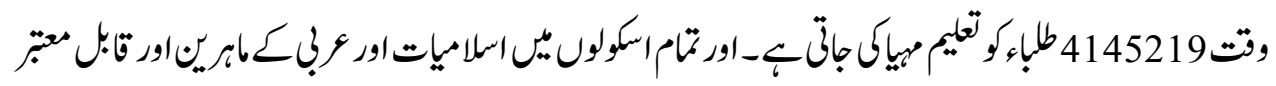

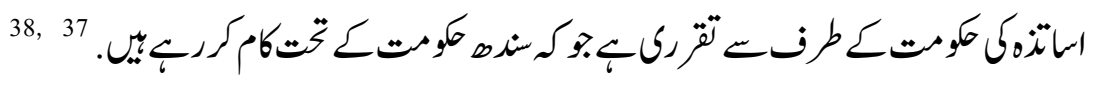

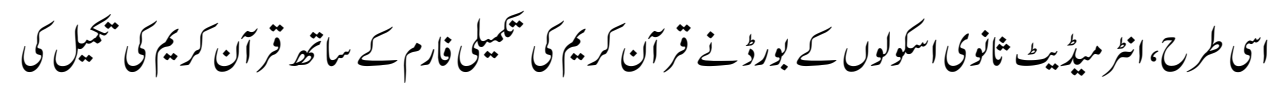

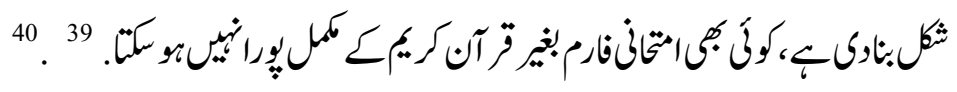

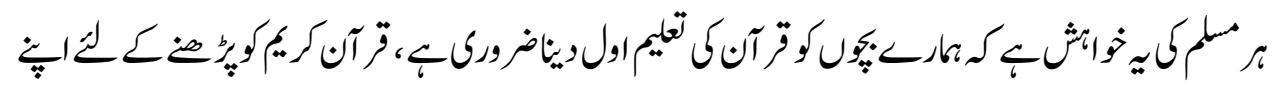

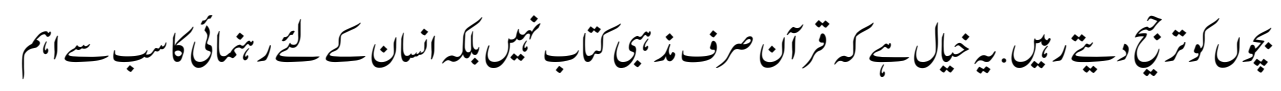

\footnotetext{
${ }^{33}$ Sachs, Jeffrey. "The end of poverty: economic possibilities for our time." European Journal of Dental Education 12.s1 (2008): 17-21

${ }_{34}^{34}$ Moullana Saleemullah, waffa qul madaris multan Pakistan vol-6, 2008

${ }^{35}$ Amin Ahsan Islahi, Tadabbur-i-Qur'an, vol. 9, 6th ed. (Lahore: Farana Foundation, 1994), p. 79

${ }^{36}$ Sindh Education Web Site

${ }^{37}$ Hussain, Shahid. "An Analysis of Government Primary Schools' Characteristics Influencing Student Achievement in Northern Sindh." Bulletin of Education and Research 40, no. 1 (2018): 89-98.

${ }_{30}^{38}$ Sindh Education Web Site

${ }^{39}$ Soomro, Manzoor Hussain, and Saima Huma Tanveer. "Ethics and Education in Pakistan: Principles, Policies and Practice." In Children and Sustainable Development, pp. 385-396. Springer, Cham, 2017. 


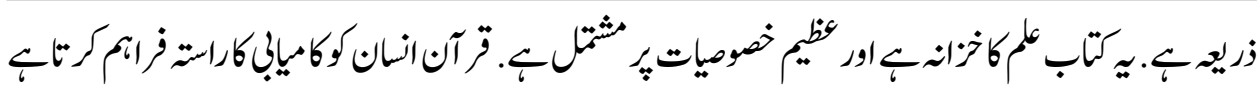

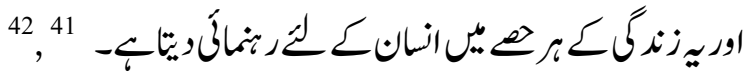

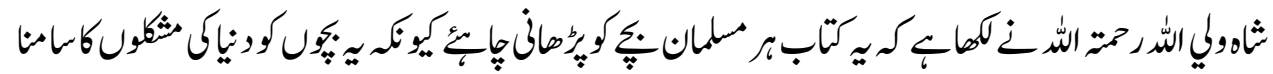

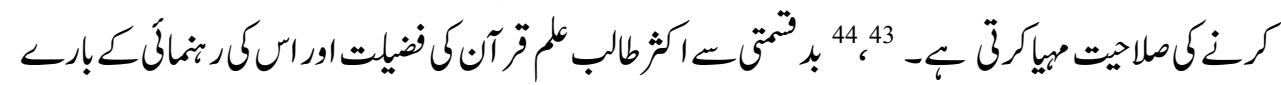

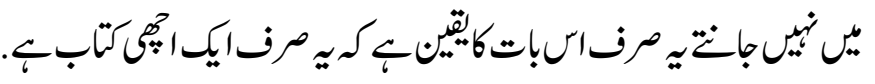

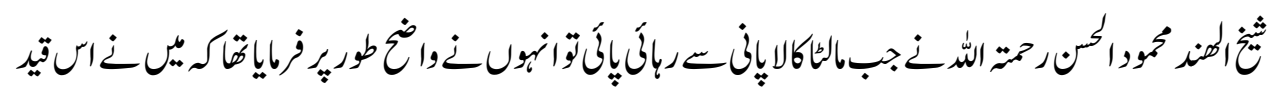

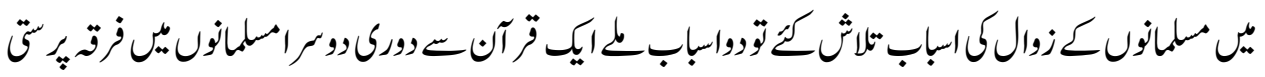

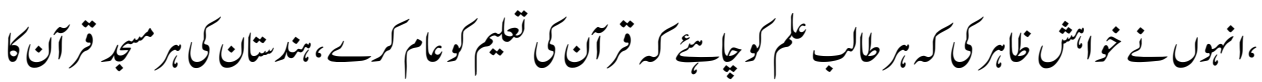

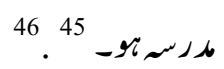

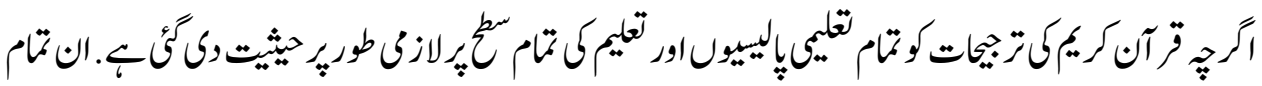

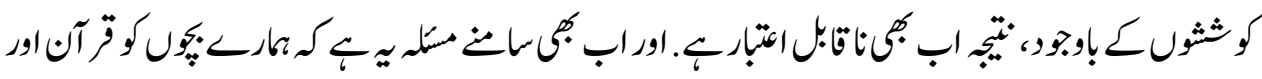

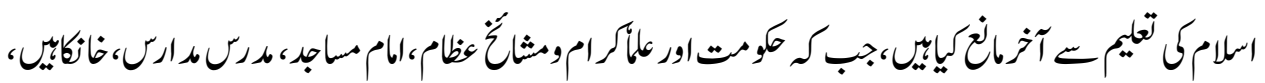

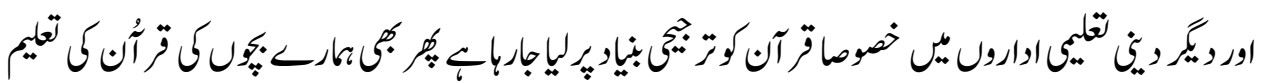

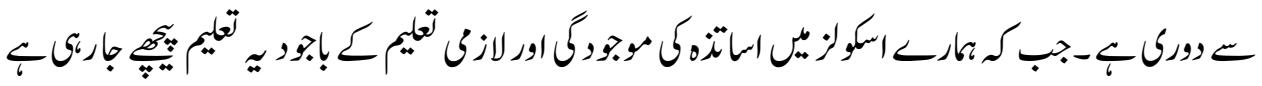

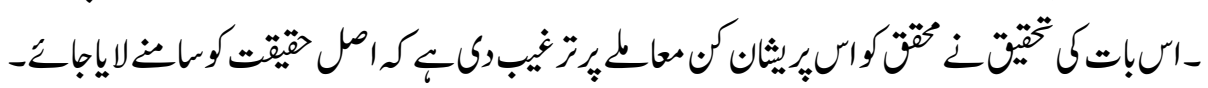

\footnotetext{
${ }^{41}$ Sachs, Jeffrey. "The end of poverty: economic possibilities for our time." European Journal of Dental Education 12.s1 (2008): 17-21.

${ }^{42}$ Perveen Tahir, Islami Essential Zimon Secondary Schools (2003) p.3. 3.7

${ }^{43}$ Osler, A., \&Hussain, Z, Parental choice and schooling: Some factors influencing Muslim mothers' decisions about the education of their daughters. Cambridge Journal of Education, . (1995). 25(3), 327-347.

${ }^{44}$ Hafiz Haqqani . madaris taleem 2002

${ }^{45}$ Schneider, Suzanne. Mandatory Separation: Religion, Education, and Mass Politics in Palestine. Stanford University Press, 2018.

${ }^{46}$ Ahmed Dr Israr . ders-quran khadim ul mon=vement Karachi
} 


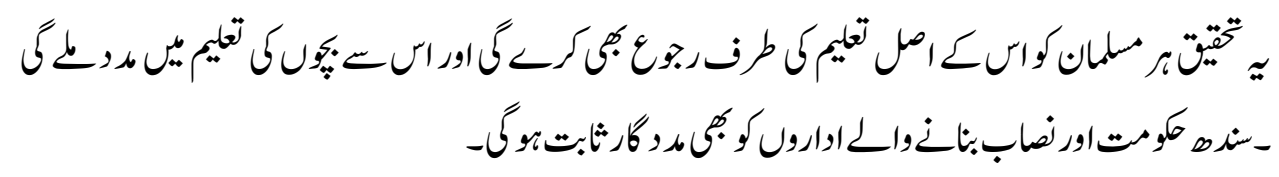

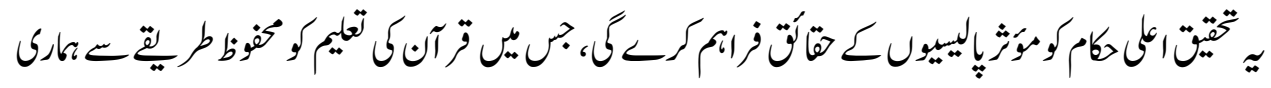

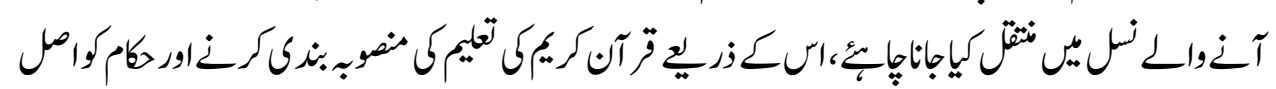

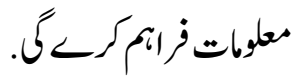

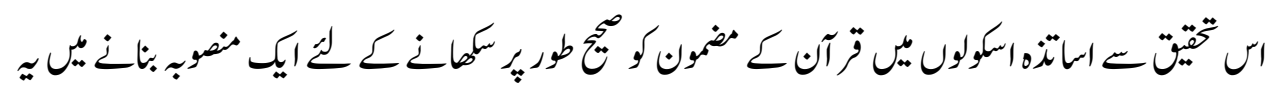
معاوكثابت بوكى

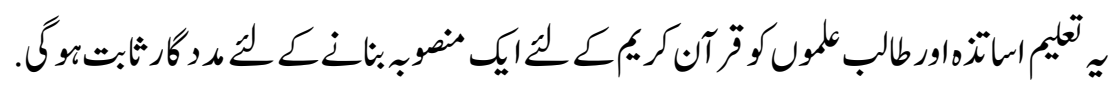

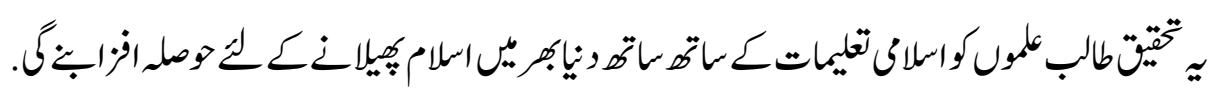

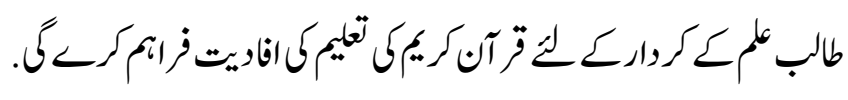

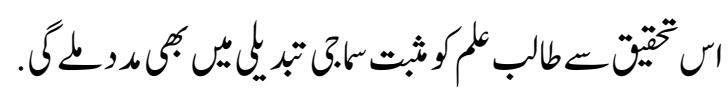

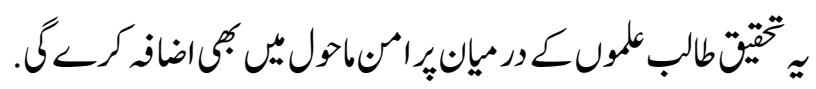

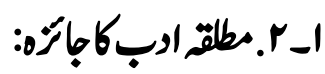

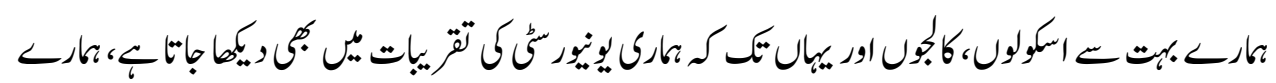

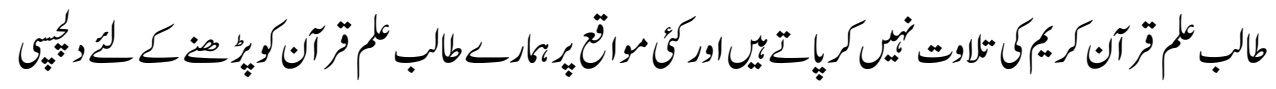

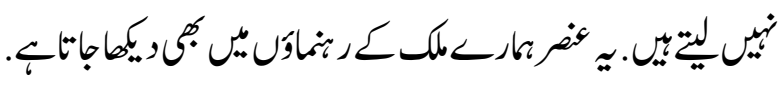




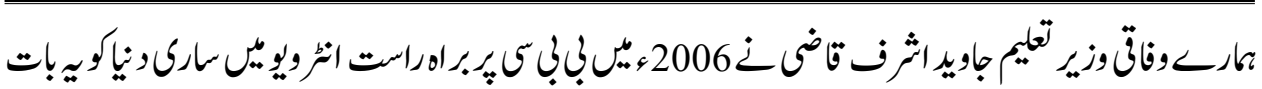

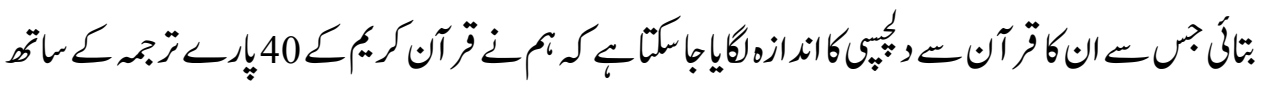

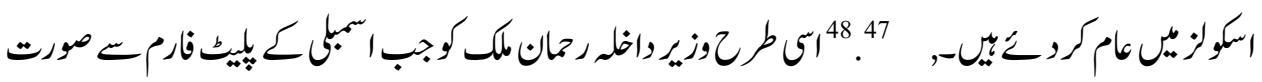

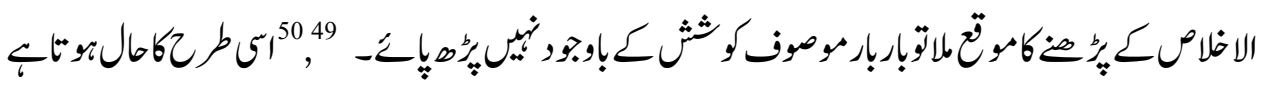

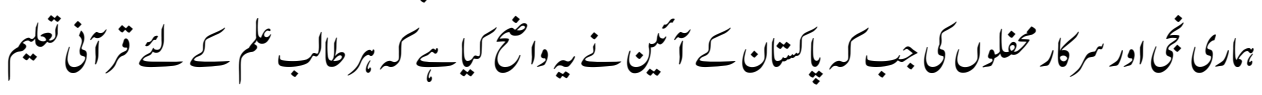

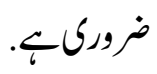

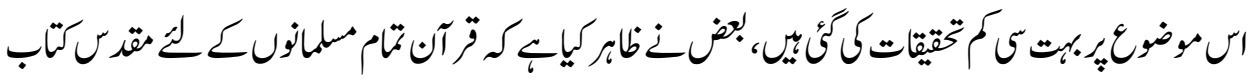

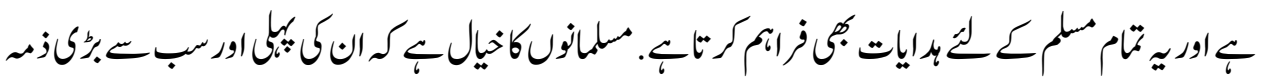

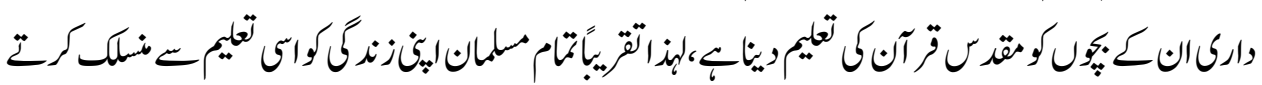

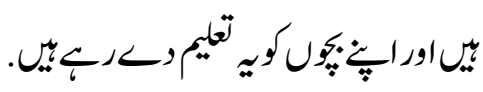

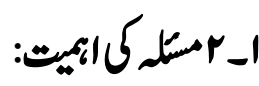

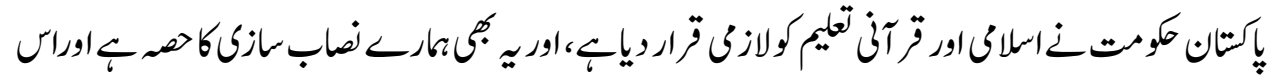

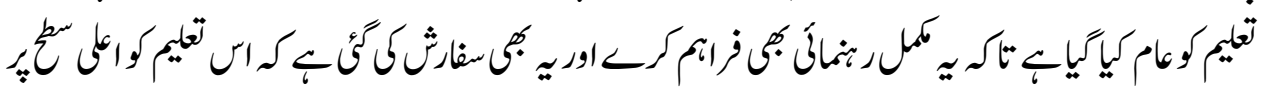

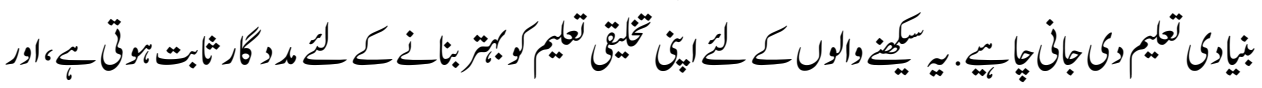

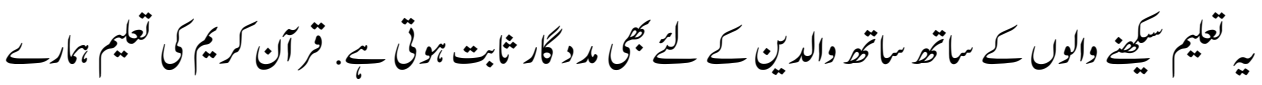

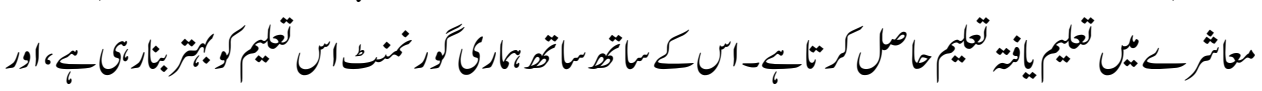

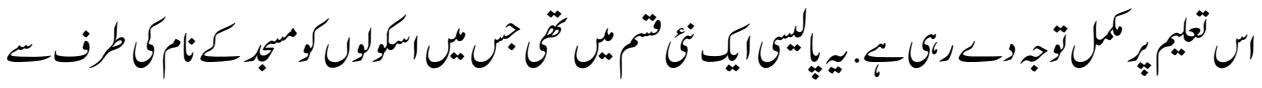

\footnotetext{
${ }^{47}$ Jalinderikhairulmadarismultan. Monthly Islamic magazine 2006, p-4.5

48 Jalundery Muhammad Hanief . muqdama madaris ,Modern eduation\& Islamic Education in Pakstani,.2011

49 Ali, ShaheenSardar. "Law, Islam and the women's movement in Pakistan." In International Perspectives on Gender and Democratization, pp. 41-63. Palgrave Macmillan UK, 2000.

50 Jalundery Muhammad Hanief, muqdama madaris ,Modern education\& Islamic Education in Pakstani,.2011
} 


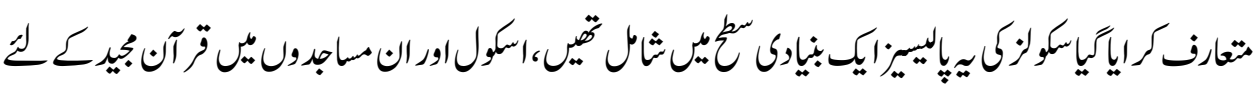

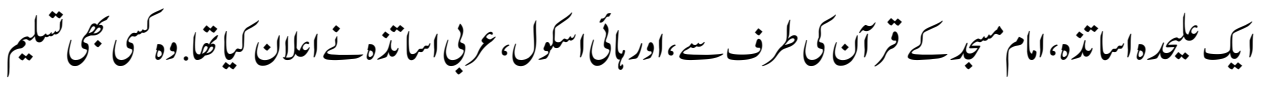

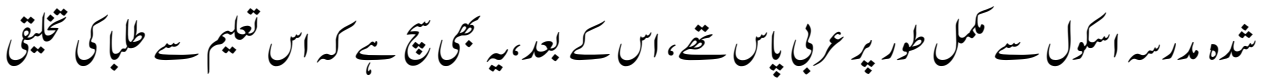

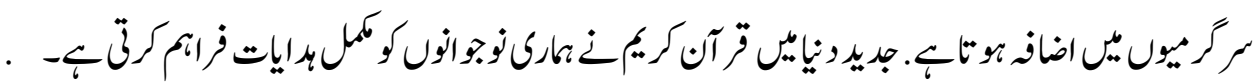

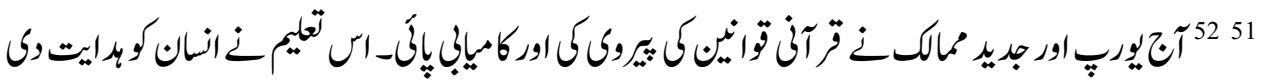

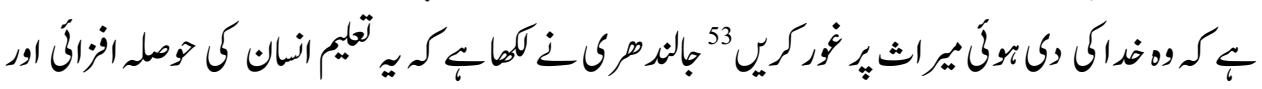

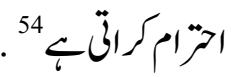

\section{rـ بيانمتلم:}

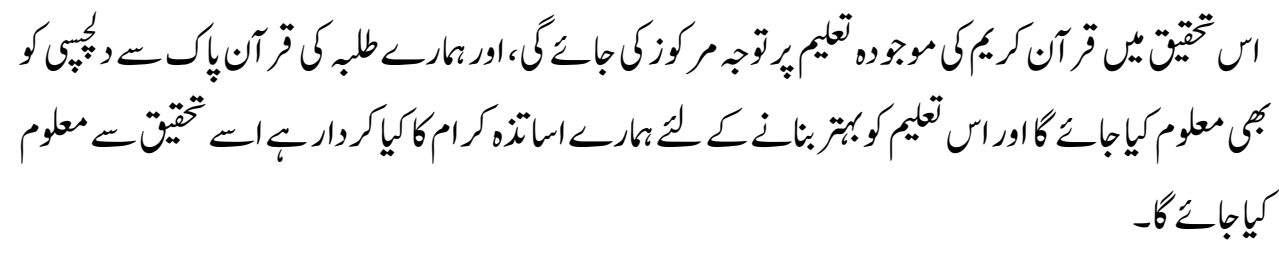

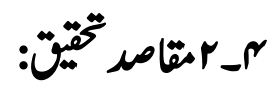

1

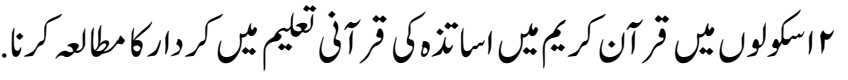

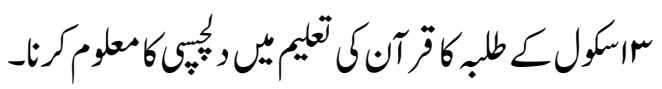

\footnotetext{
51 Astin, Alexander W., Helen S. Astin, and Jennifer A. Lindholm. Cultivating the spirit: How college can enhance students' inner lives. John Wiley \& Sons, 2010.

52 Stowasser, B. F. Women in the Qur'an, Traditions, and Interpretation. Oxford University Press. 1994.

${ }^{53}$ Halijwee Mahammed Murd . al ,nasehat magazine islami= sucker , 1999,

54 Jalundery Muhammad Hanief. muqdama madaris ,Modern eduation\& islamic Education in Pakstani,.2011
} 


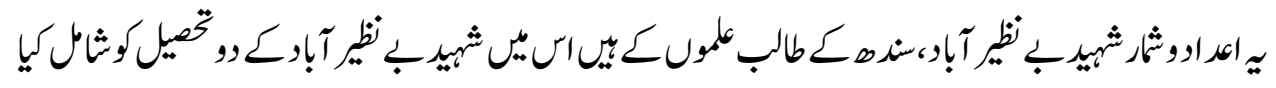

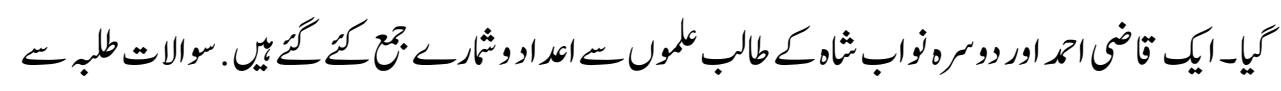

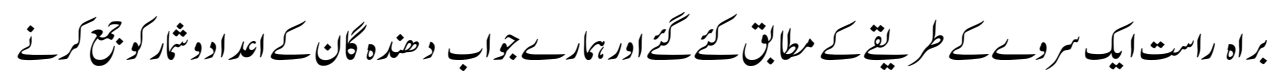

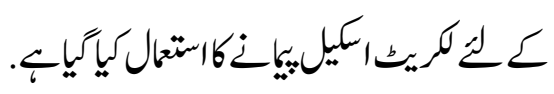
ا-مسآباوكونمون:

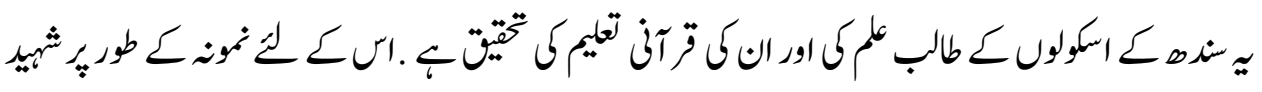

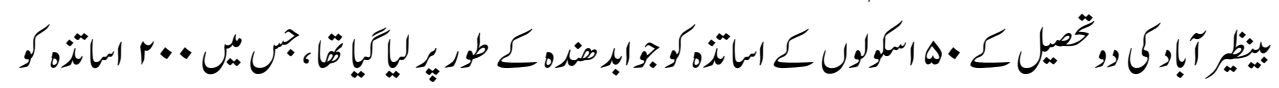

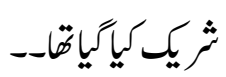

\section{هــمر يقّرك:}

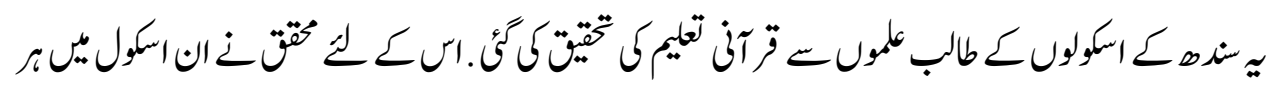

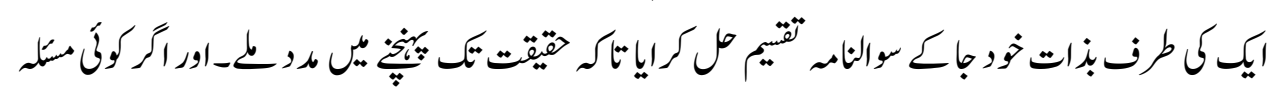

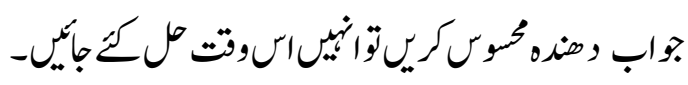




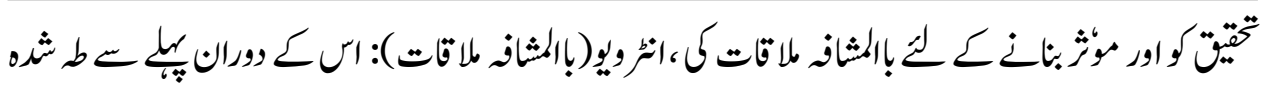

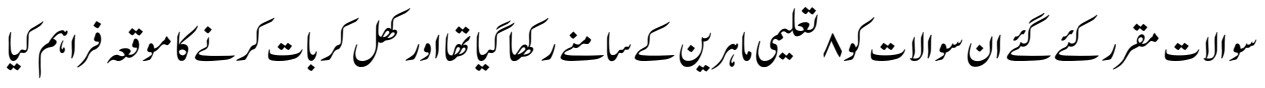

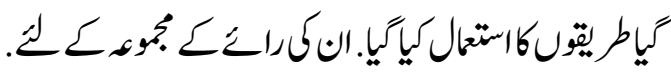

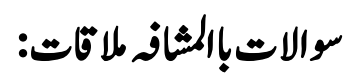

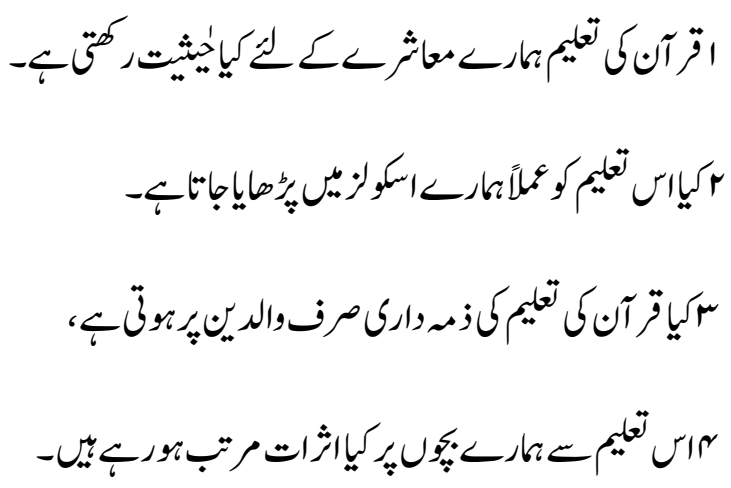

\section{بالمثاف ملاقات عنماث:}

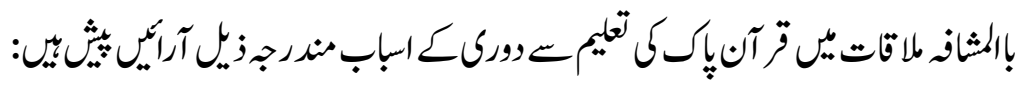

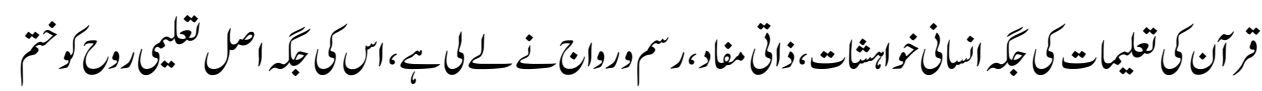

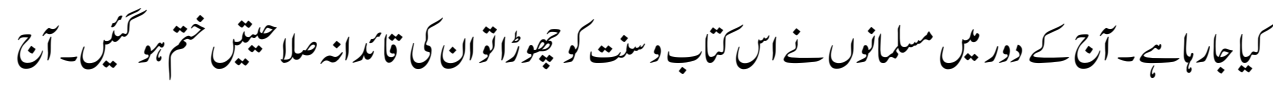

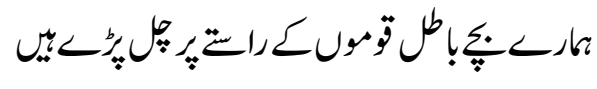

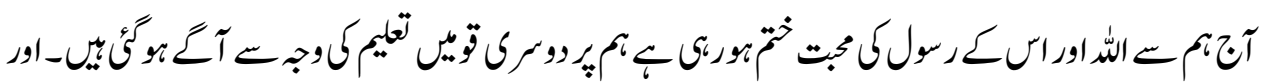

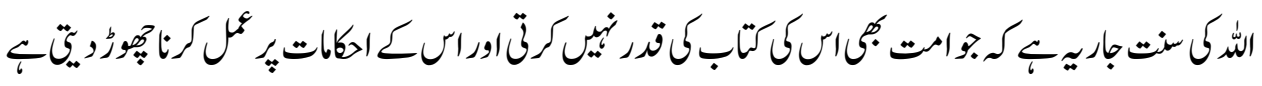

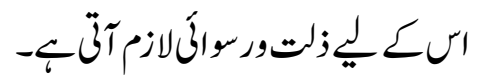

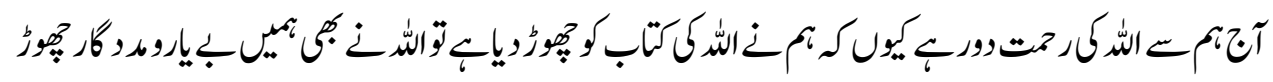

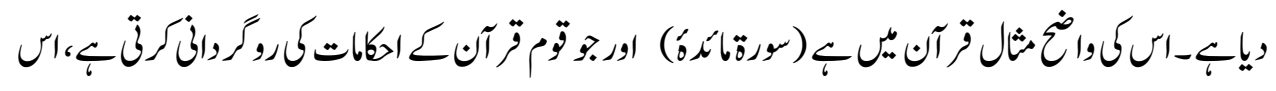




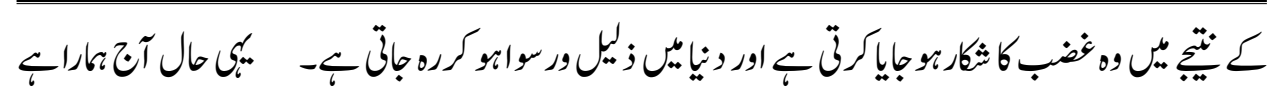

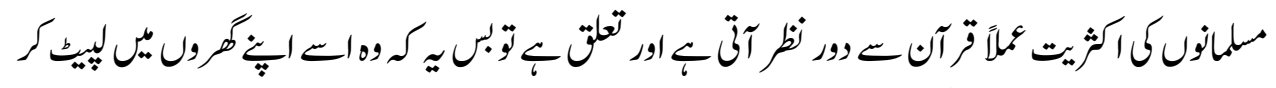

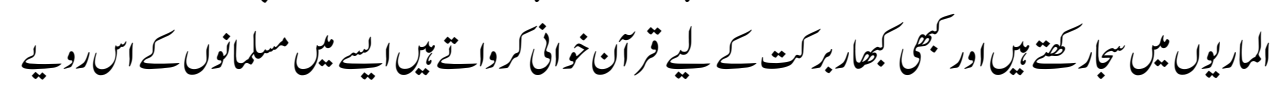
6 نثوهمياكري

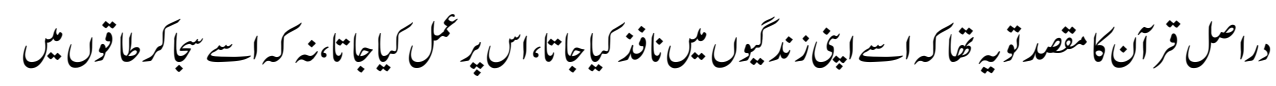

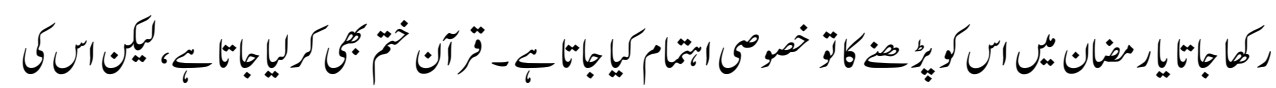

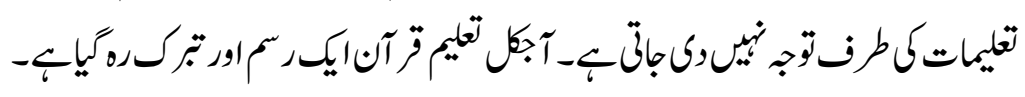

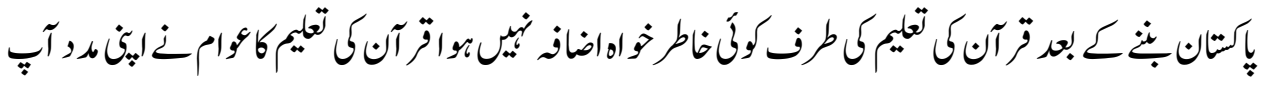

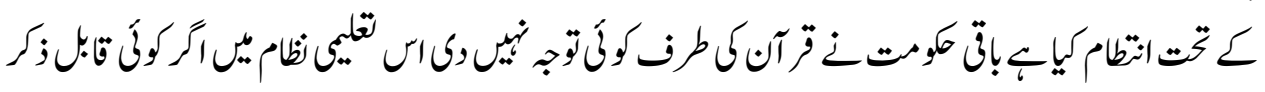

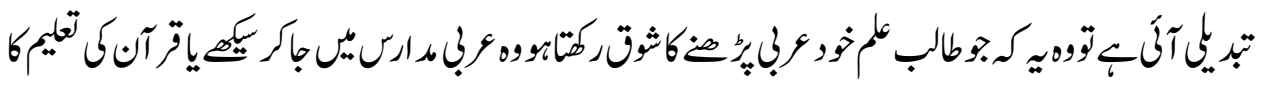

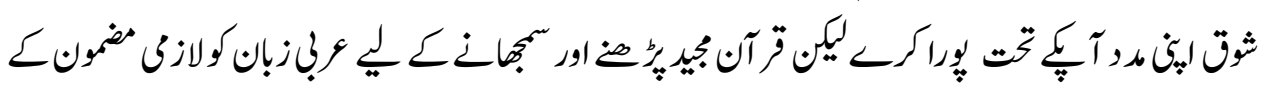

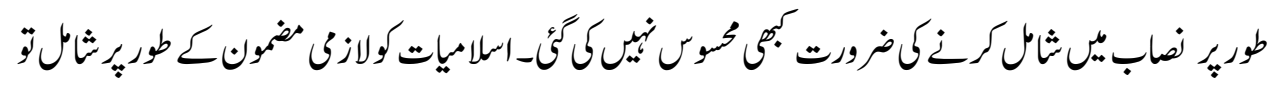

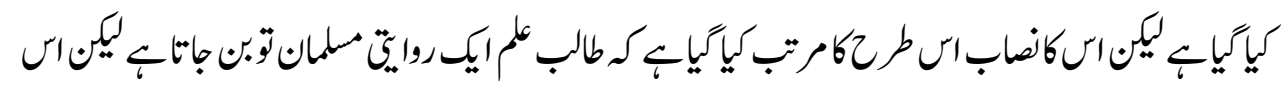

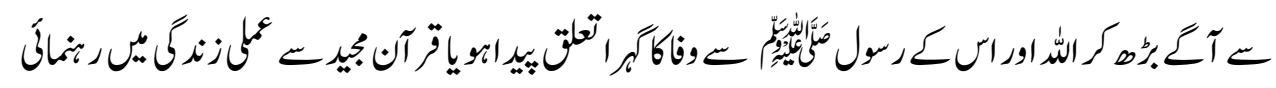

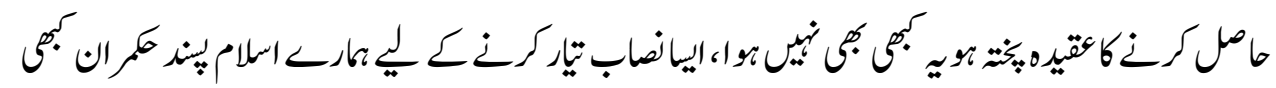

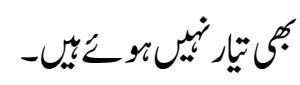

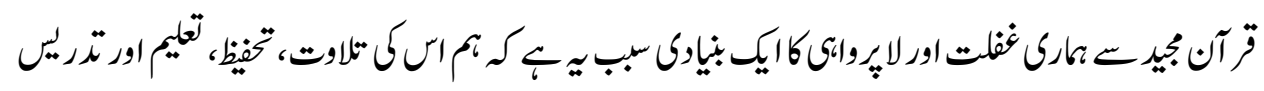

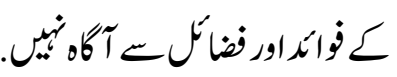

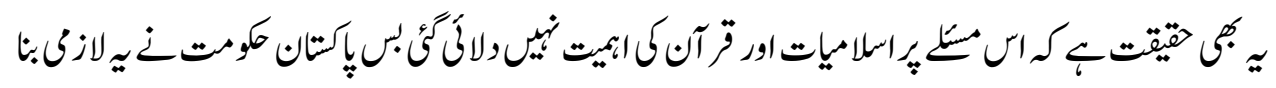

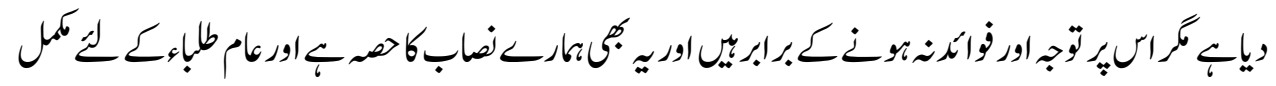

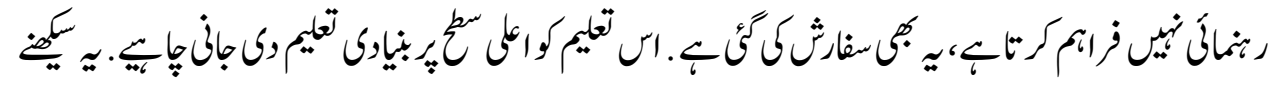

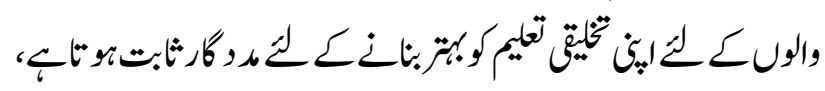




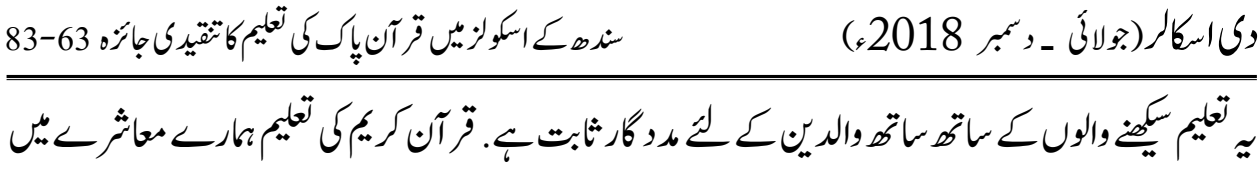

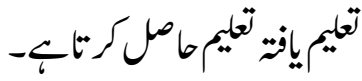

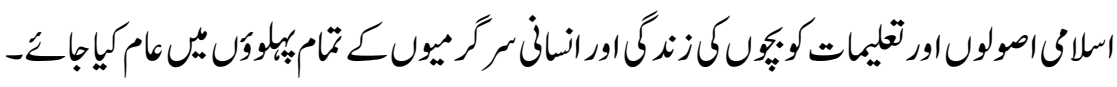

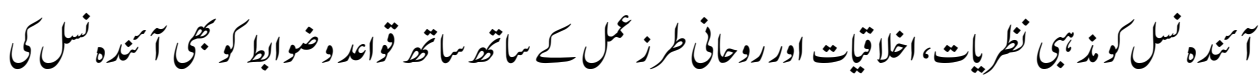

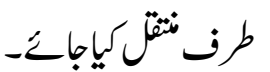

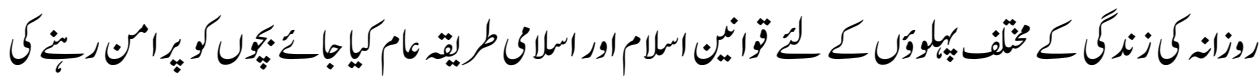

$$
\begin{aligned}
& \text { تهيم وكاجــ } \\
& \text { اعداووثما: }
\end{aligned}
$$

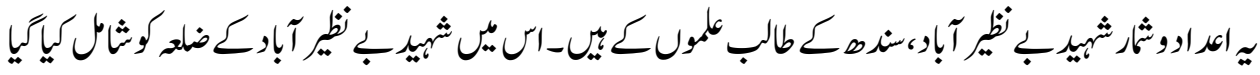

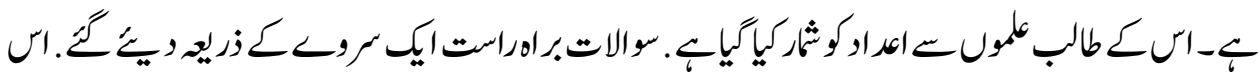

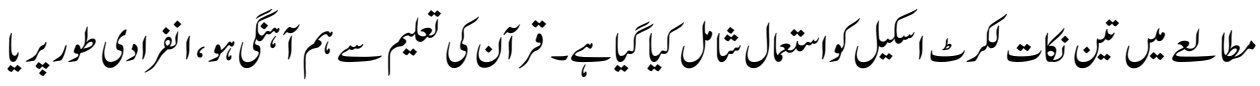

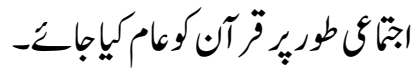

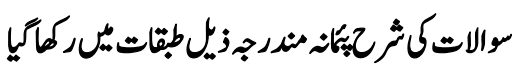

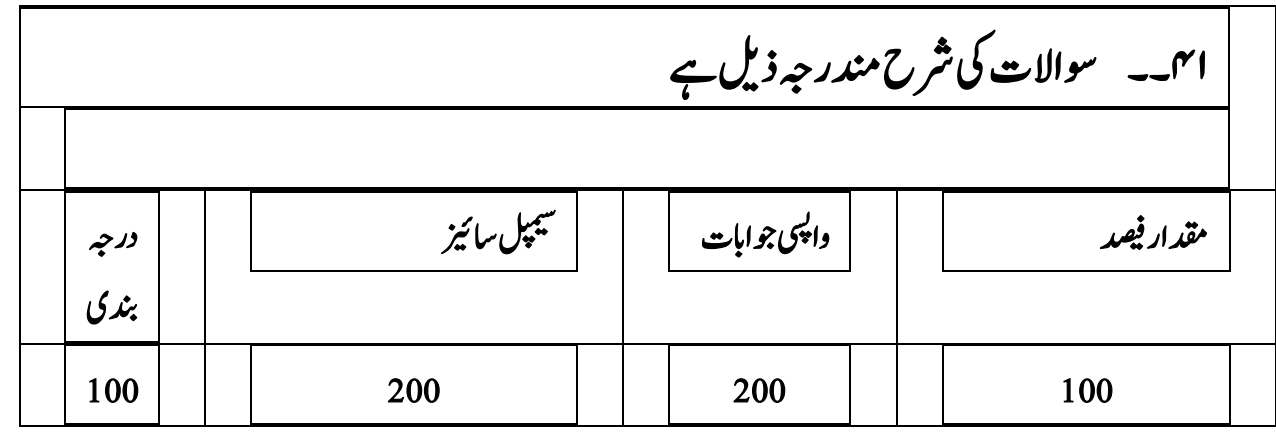

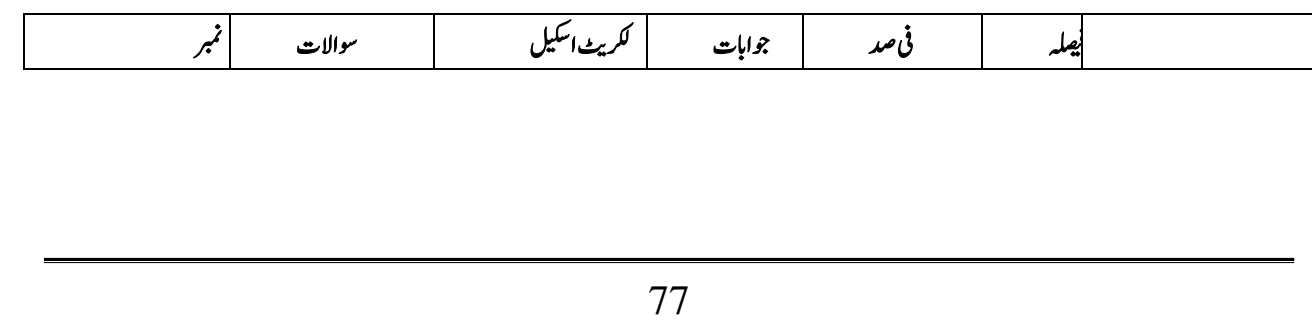




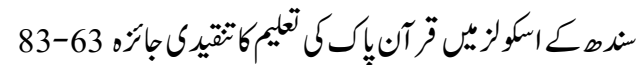

وكاسطالر(بولأ ــ ـبمر 2018ء)

\begin{tabular}{|c|c|c|c|c|c|c|}
\hline & 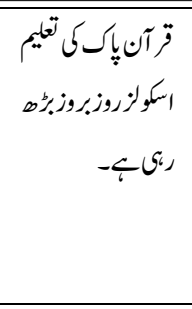 & 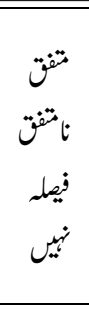 & $\begin{array}{l}3 \\
0 \\
{ }^{162} \\
8\end{array}$ & $\begin{array}{l}15 \\
81 \\
04\end{array}$ & 安 & 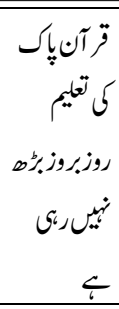 \\
\hline 2 & 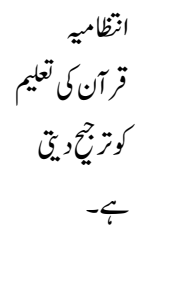 & 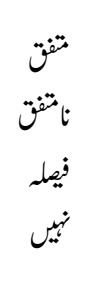 & $\begin{array}{c}6 \\
3 \\
133 \\
0 \\
4\end{array}$ & $\begin{array}{c}31.5 \\
66.5 \\
02\end{array}$ & : & 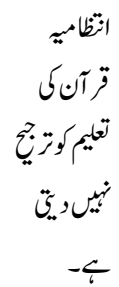 \\
\hline 3 & 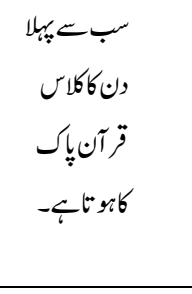 & 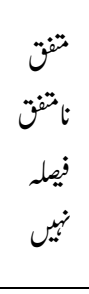 & $\begin{array}{c}4 \\
0 \\
141 \\
19\end{array}$ & $\begin{array}{c}20 \\
70.5 \\
09.5\end{array}$ & : & 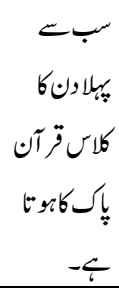 \\
\hline 4 & 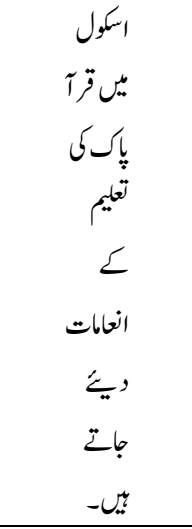 & 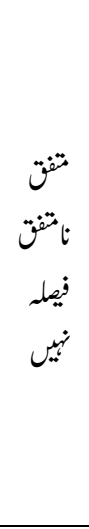 & $\begin{array}{r}76 \\
109 \\
15\end{array}$ & $\begin{array}{c}38 \\
58.5 \\
7.5\end{array}$ & : & 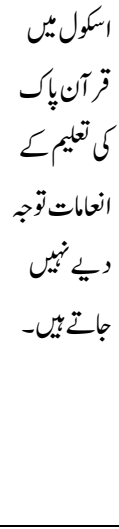 \\
\hline 5 & كر & 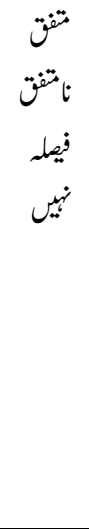 & $\begin{array}{r}41 \\
143 \\
16\end{array}$ & $\begin{array}{c}20.5 \\
71.5 \\
08\end{array}$ & : & 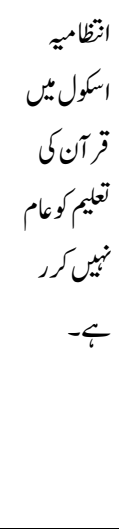 \\
\hline
\end{tabular}




\begin{tabular}{|c|c|c|c|c|c|c|}
\hline \multicolumn{4}{|c|}{ 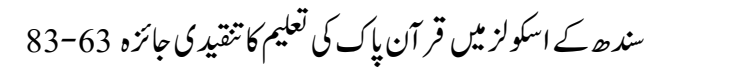 } & \multicolumn{3}{|c|}{ وكاسكالر(ولأَ ــ ـمبر 2018ء) } \\
\hline 6. & 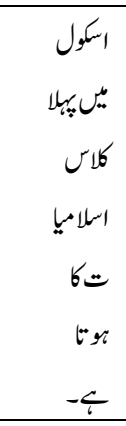 & 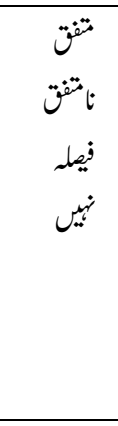 & $\begin{array}{r}109 \\
15\end{array}$ & $\begin{array}{c}38 \\
58.5 \\
7.5\end{array}$ & : & 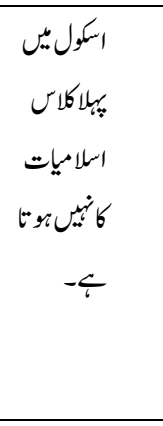 \\
\hline 7. & 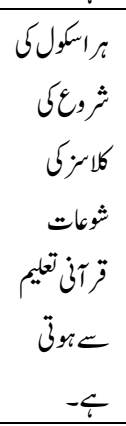 & 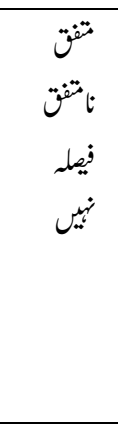 & $\begin{array}{r}66 \\
119 \\
15\end{array}$ & $\begin{array}{c}33 \\
59.5 \\
07.5\end{array}$ & : & 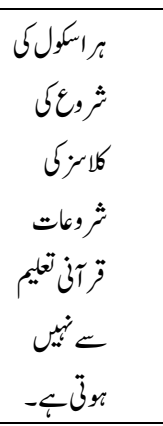 \\
\hline 8. & 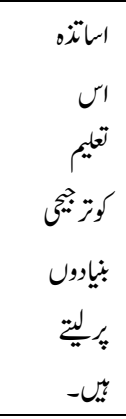 & 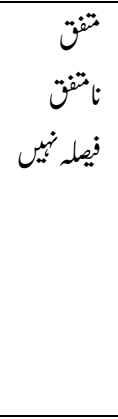 & $\begin{array}{r}34 \\
156 \\
10\end{array}$ & $\begin{array}{l}17 \\
78 \\
05\end{array}$ & : & 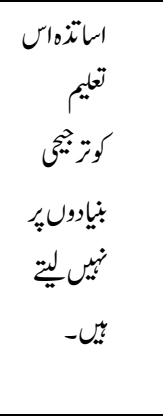 \\
\hline 9. & 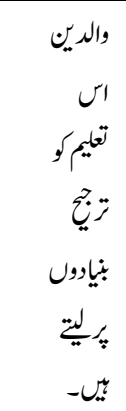 & 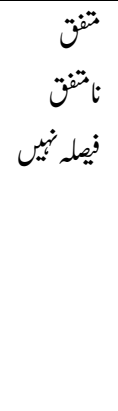 & $\begin{array}{r}79 \\
102 \\
19\end{array}$ & $\begin{array}{c}39.5 \\
51 \\
09.5\end{array}$ & : & 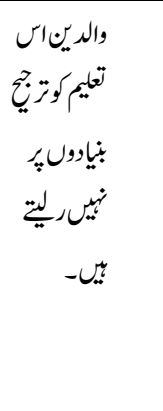 \\
\hline 10 & 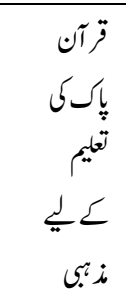 & 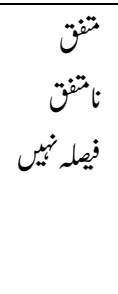 & $\begin{array}{l}94 \\
88 \\
18\end{array}$ & $\begin{array}{l}47 \\
44 \\
09\end{array}$ & is & كَّ قَّليمك \\
\hline
\end{tabular}




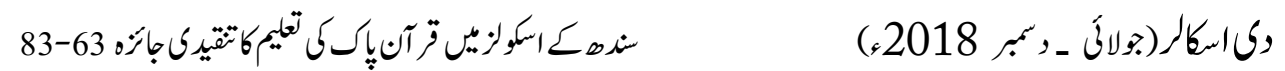

\begin{tabular}{|c|c|c|c|c|c|c|}
\hline & 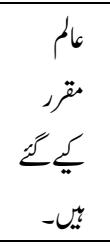 & & & & & "ي \\
\hline 11. & 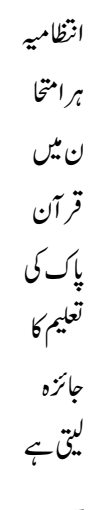 & نيمتن تيمني & $\begin{array}{r}70 \\
110 \\
20\end{array}$ & $\begin{array}{l}35 \\
55 \\
10\end{array}$ & मे & 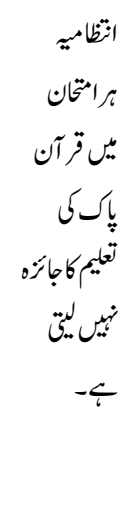 \\
\hline 12. & 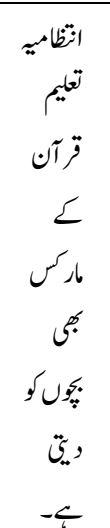 & 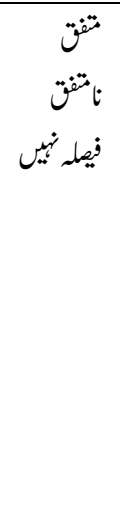 & $\begin{array}{r}105 \\
65 \\
30\end{array}$ & & bे & 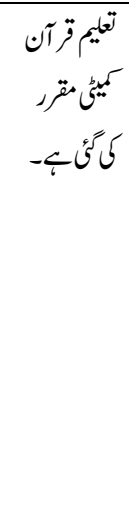 \\
\hline 13. & 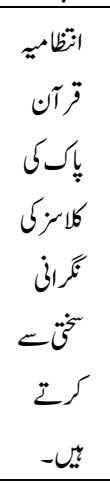 & 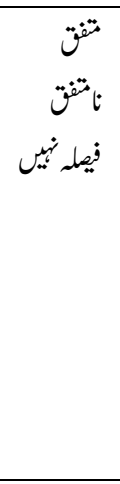 & $\begin{array}{r}40 \\
141 \\
19\end{array}$ & $\begin{array}{r}20 \\
71.5 \\
9.5\end{array}$ & मे & 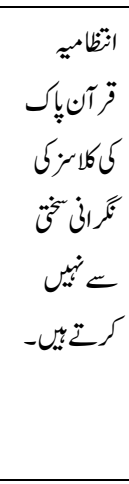 \\
\hline
\end{tabular}




\begin{tabular}{|c|c|c|c|c|c|c|}
\hline \multicolumn{4}{|c|}{ 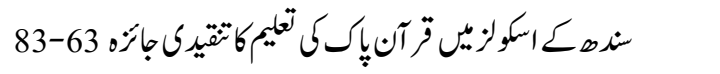 } & \multicolumn{3}{|c|}{ ركاسكالر(جولأَ ــ ـسمبر 2018؛) } \\
\hline 14. & 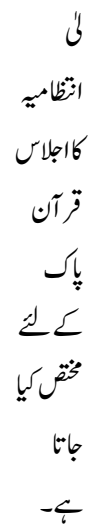 & 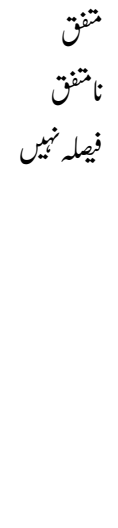 & $\begin{array}{r}41 \\
143 \\
16\end{array}$ & $\begin{array}{r}20.5 \\
71.5 \\
08\end{array}$ & : & 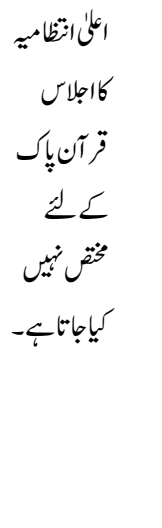 \\
\hline 15. & 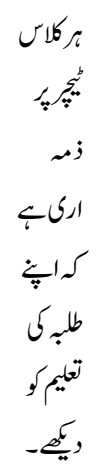 & 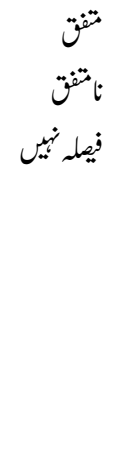 & $\begin{array}{r}76 \\
109 \\
15\end{array}$ & $\begin{array}{r}38 \\
58.5 \\
7.5\end{array}$ & : & 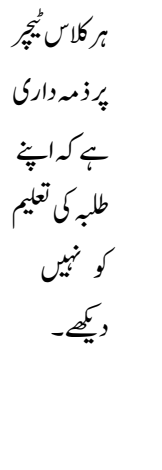 \\
\hline 16 & 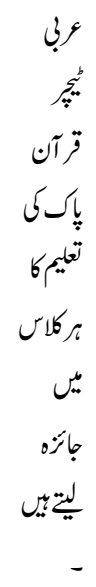 & 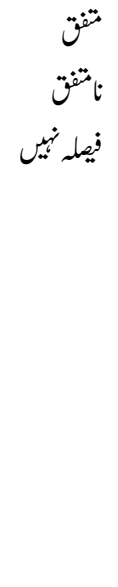 & $\begin{array}{r}76 \\
109 \\
15\end{array}$ & $\begin{array}{r}38 \\
58.5 \\
7.5\end{array}$ & : & 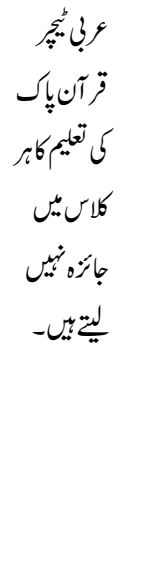 \\
\hline
\end{tabular}

1

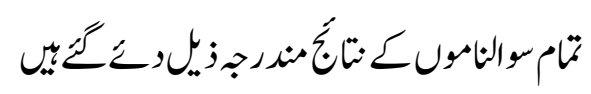




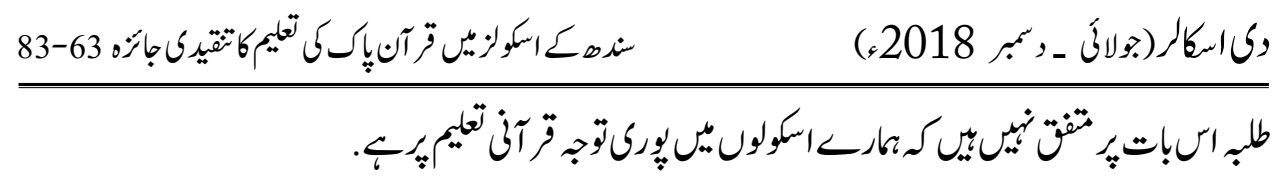

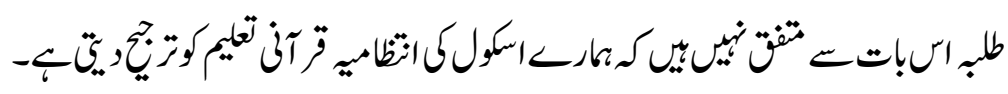

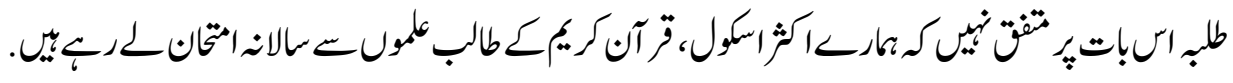

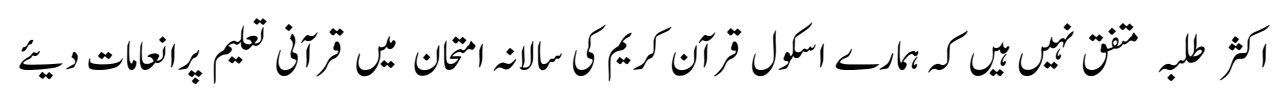
جاتبي.

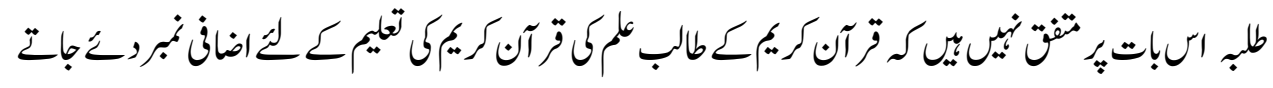

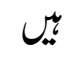

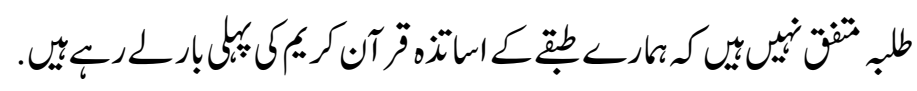

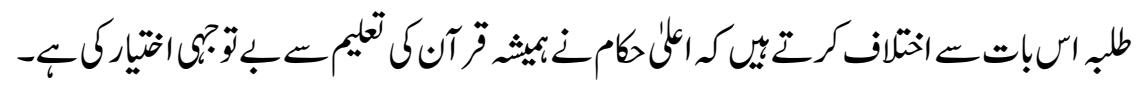

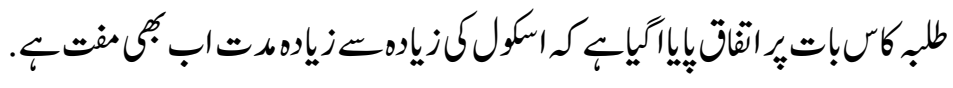

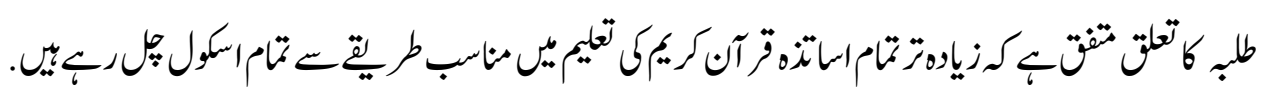

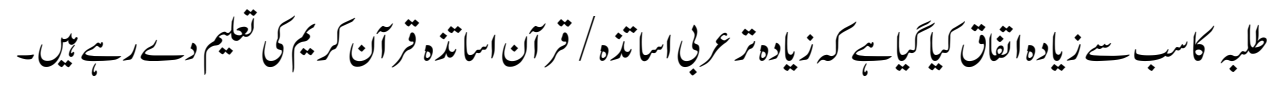
4

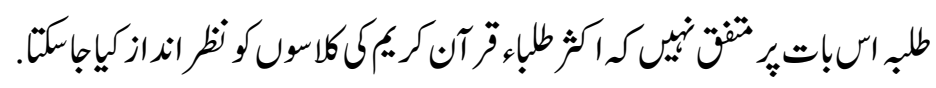

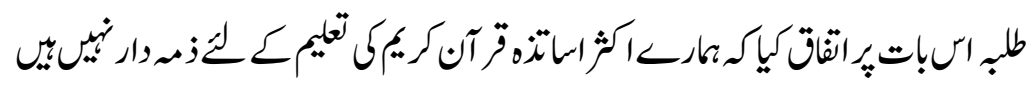

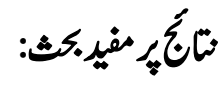

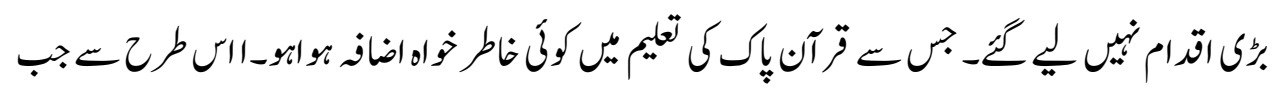




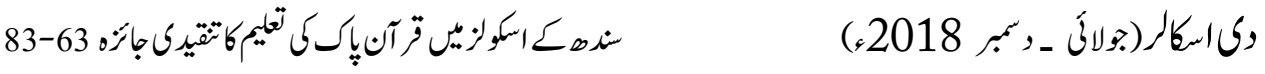

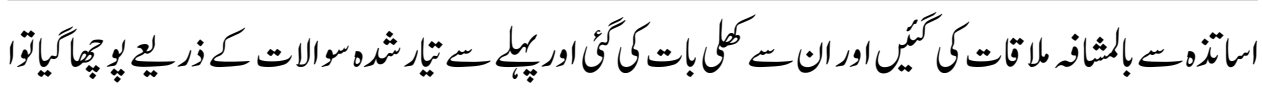

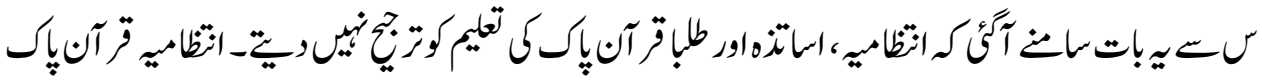

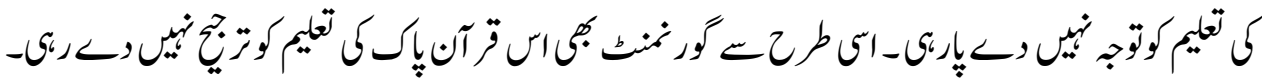

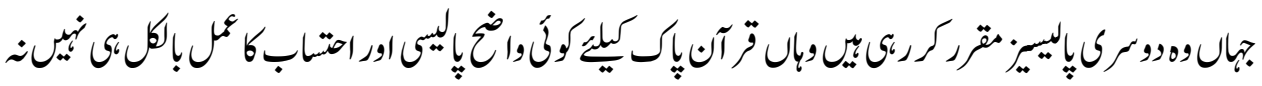

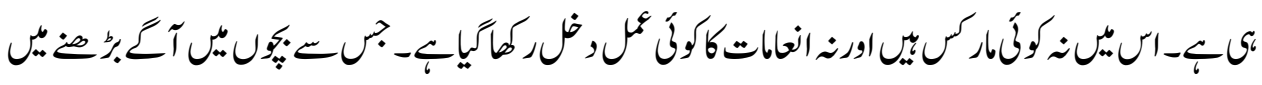

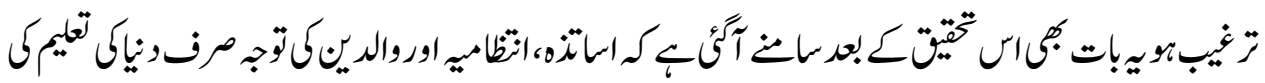

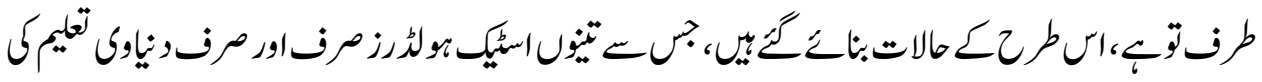

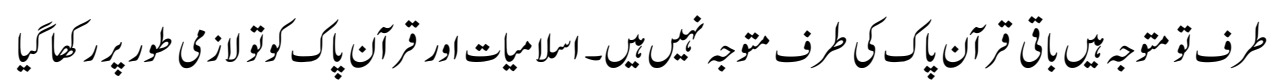

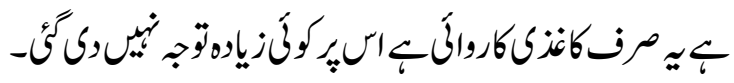

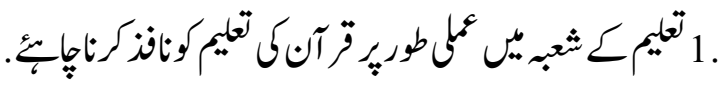

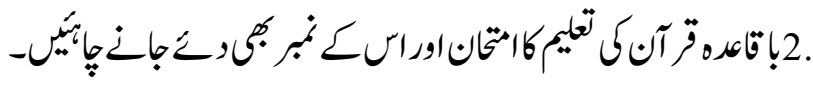

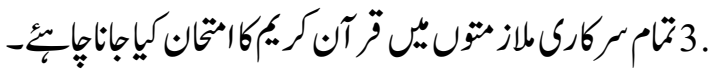

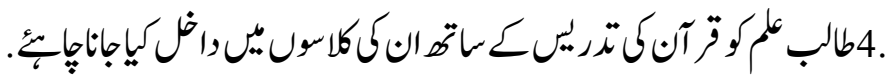

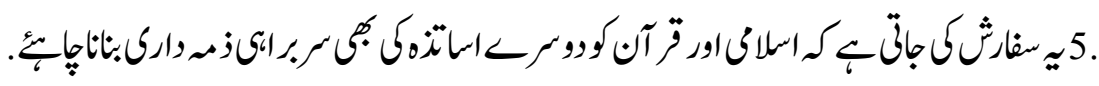

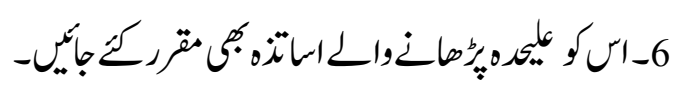

\section{(c) (1)(2)}

Attribution-NonCommercial-ShareAlike 4.0 International (CC BY-NC-SA 4.0) 